\title{
Tank 42 Sludge-Only Process Development for the Defense Waste Processing Facility (DWPF)
}

by

D. P. Lambert

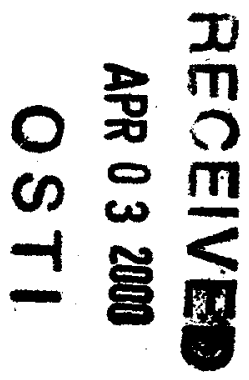

Westinghouse Savannah River Company

Savannah River Site

Aiken, South Carolina 29808

C. S. Boley

DOE Contract No. DE-AC09-96SR18500

This paper was prepared in connection with work done under the above contract number with the U. S. Department of Energy. By acceptance of this paper, the publisher and/or recipient acknowledges the U.S. Government's right to retain a nonexclusive, royalty-free license in and to any copyright covering this paper, along with the right to reproduce and to authorize others to reproduce all or part of the copyrighted paper. 
WSRC-RP-98-00149, Revision 1

RECORDS ADMINISTRATION

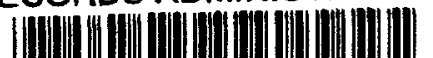

R0088587

\section{TANK 42 SLUDGE-ONLY PROCESS DEVELOPMENT FOR THE DEFENSE WASTE PROCESSING FACILITY (DWPF) (U)}

\section{INFORMATION ONLY}

D. P. Lambert

C. S. Boley

Westinghouse Savannah River Company

Savannah River Site -

Aiken, SC 29808

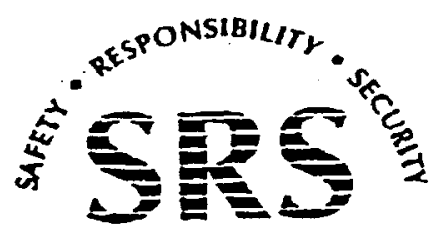

PREPARED FOR THE U.S. DEPARTMENT OF ENERGY UNDER CONTRACT NO. DE-AC09-96SR18500 


\section{DISCLAIMER}

This report was prepared as an account of work sponsored by an agency of the United States Government. Neither the United States Government nor any agency thereof, nor any of their employees, makes any warranty, express or implied, or assumes any legal liability or responsibility for the accuracy, completeness, or usefulness of any information, apparatus, product or process disclosed, or represents that its use would not infringe privately owned rights. Reference herein to any specific commercial product, process or service by trade name, trademark, manufacturer, or otherwise does not necessarily constitute or imply its endorsement, recommendation, or favoring by the United States Government or any agency thereof. The views and opinions of authors expressed herein do not necessarily state or reflect those of the United States Government or any agency thereof.

This report has been reproduced directly from the best available copy.

Available for sale to the public, in paper, from: U.S. Department of Commerce, National Technical Information Service, 5285 Port Royal Road, Springfield, VA 22161, phone: (800) 553-6847

fax: (703) 605-6900

email: orders@ntis.fedworld.gov

online ordering: http://www.ntis.gov/ordering.htm

Available electronically at http://www.doe.gov/bridge

Available for a processing fee to U.S. Department of Energy and its contractors, in paper, from: U.S. Department of Energy, Office of Scientific and Technical Information, P.O. Box 62, Oak Ridge, TN 37831-0062, phone: (865) 576-8401

fax: (865) 576-5728

email: reports@adonis.osti.gov 


\section{DISCLAIMER}

Portions of this document may be illegible in electronic image products. Images are produced from the best available original document. 
WSRC-RP-98-00149, Revision 1 Distribution Category: To Be Determined

Keywords: DWPF, CPC, Sludge, Tank 42

Retention: Permanent

\title{
TANK 42 SLUDGE-ONLY PROCESS DEVELOPMENT FOR THE DEFENSE WASTE PROCESSING FACILITY (DWPF) (U)
}

\author{
C. S. Boley \\ D. P. Lambert
}

Publication Date: September 2, 1998 


\section{APPROVALS}

Is am

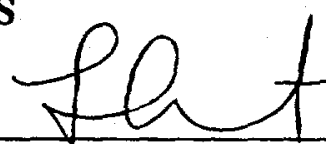

D. P. Lambert, Author

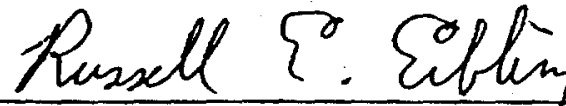

R. E. Eibling, Technical Reviewer

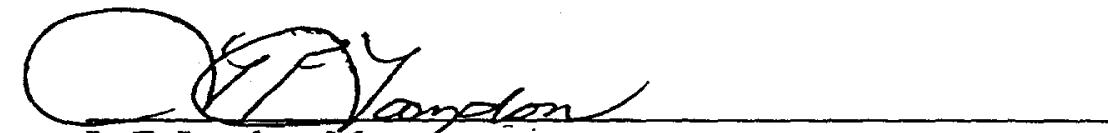

L. F. Landon, Manzger . .

Eublectionche

E. W. Holtzscheiter, Defense Waste Processing Technology

$$
\begin{gathered}
\frac{9-2-98}{\text { Date }} \\
\frac{9-2-98}{\text { Date }}
\end{gathered}
$$$$
\frac{9-2-98}{\text { Date }}
$$

$\frac{9-2-98}{\text { Date }}$ 


\section{EXECUTIVE SUMMARY}

DWPF requested the development of a sludge-only process for Tank 42 sludge (HLWDWPF/TTR-970134) since at the current processing rate, the Tank 51 sludge has been projected to be depleted as early as August 1998. Testing was completed using a nonradioactive Tank 42 sludge simulant. The testing was completed under a range of operating conditions, including worst case conditions, to develop the processing conditions for radioactive Tank 42 sludge. The existing Tank 51 sludge-only process is adequate with the exception that $10 \%$ additional acid is recommended during SRAT processing to ensure adequate destruction of nitrite during the SRAT cycle.

The following points summarize the major conclusions of the testing:

- Hydrogen and nitrous oxide $\left(\mathrm{N}_{2} \mathrm{O}\right)$ generation rates were well below DWPF operating limits and design bases, even under the worst case operating conditions of this testing.

- The SME product composition passed the Product Consistency Test (PCT) and met all requirements for SME acceptability of the Process Composition and Control System except for the processing constraints of high viscosity and liquidus.

- No processing problems such as foaming were noted in these small-scale experiments.

- The process was demonstrated under both the more oxidizing conditions of the current DWPF sludge-only process and the more.reducing conditions recommended by SRTC to minimize foaming in the melter and minimize corrosion of melter refractory and Inconel ${ }^{\mathrm{TM}} 690$.

- Testing in the SRTC shielded cells with radioactive Tank 42 sludge will demonstrate the process conditions under nominal operating conditions.

- The addition of $137.5 \%$ of the stoichiometrically required acid will ensure the nitrite is sufficiently destroyed during the twelve hour boiling period. This is $10 \%$ higher than had been recommended by the Tank 51 Alternative Sludge Only Flowsheet. 
Westinghouse Savannah River Company

Savannah River Technology Center

Table of Contents

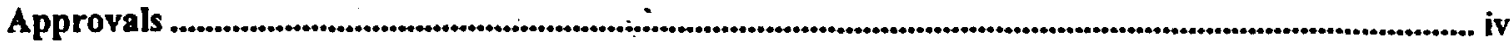

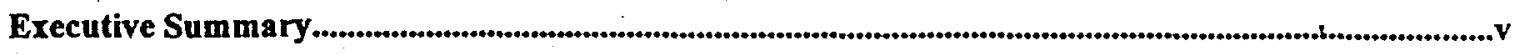

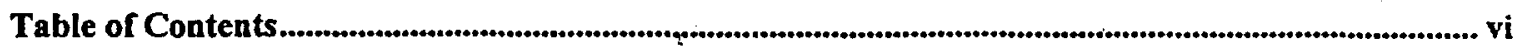

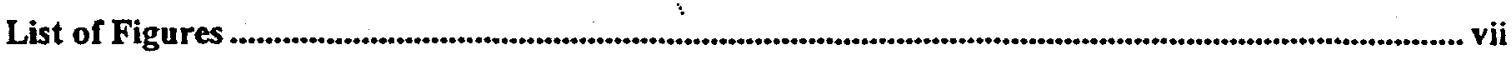

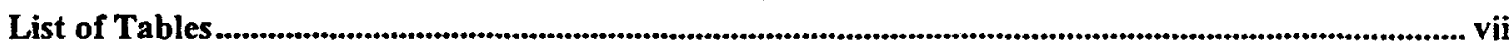

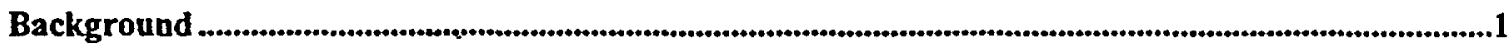

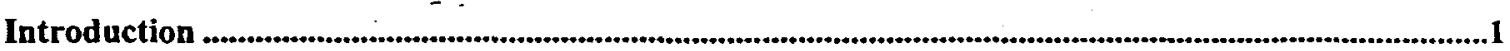

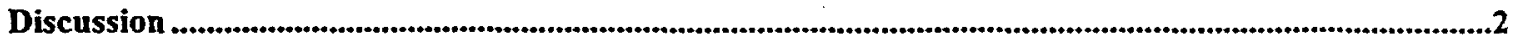

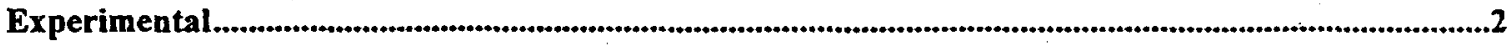

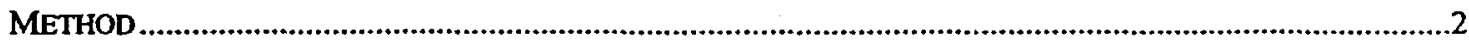

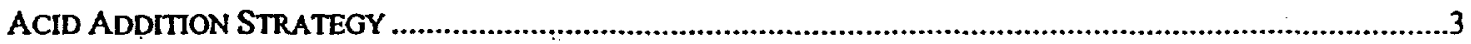

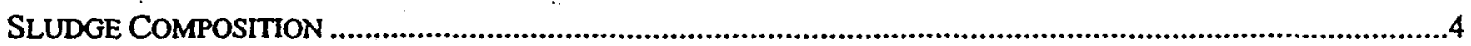

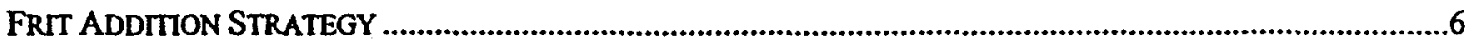

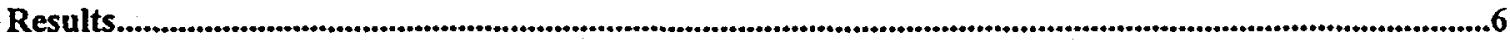

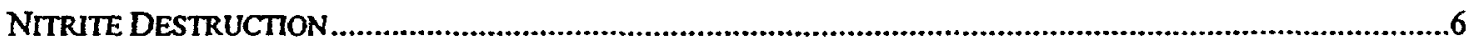

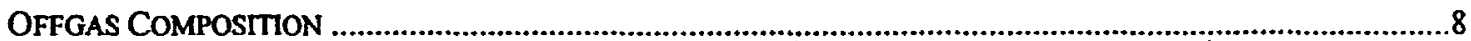

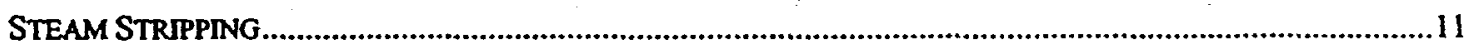

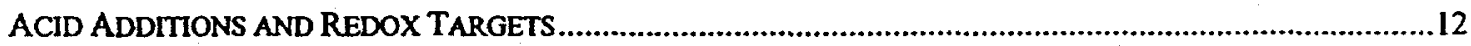

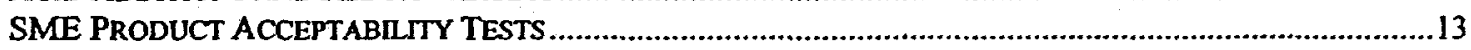

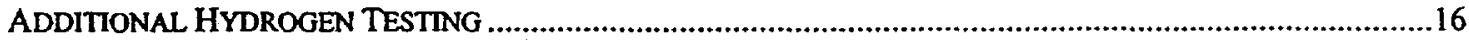

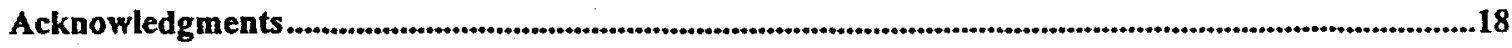

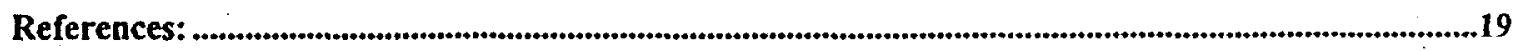

Appendix A - Experimental Setup and Laboratory Procedure...................................................... A-1

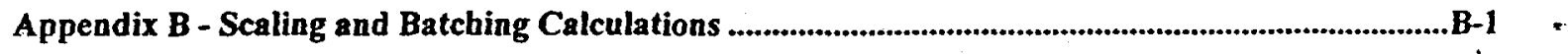

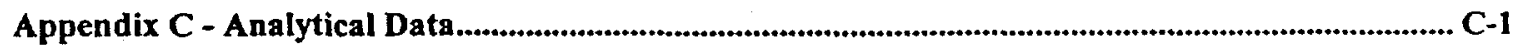




\section{LIST OF FIGURES}

Figure 1 - Nitrite Destruction. 7

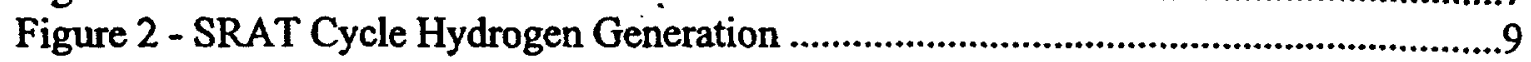

Figure 3 - SME Cycle Hydrogen Generation ....................................................................10

\section{LIST OF TABLES}

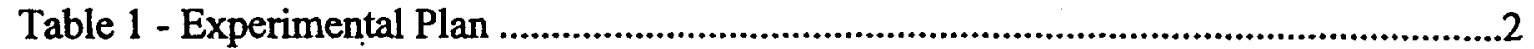

Table 3 - Sludge Properties Comparison ......................................................................4

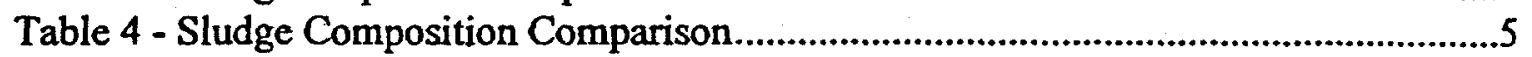

Table 5 - Tank 42 SRAT Product Nitrite Concentration ....................................................

Table 6 - Hydrogen Generation Summary (DWPF Basis) ...................................................

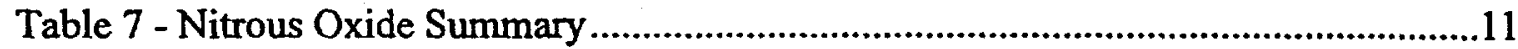

Table 8 - SRAT Product Mercury Concentration ...........................................................11

Table 9 - Acid Addition and Redox Target ...............................................................12

Table 10 - Predicted versus Actual Redox (F-N) of Melter Feeds ....................................13

Table 11 - Predicted versus Actual Redox $\left(\mathrm{Fe}^{+2} / \Sigma \mathrm{Fe}\right.$ ) of Melter Feeds ...........................13

Table 12 - PCCS Acceptability Data .........................................................................14

Table 13 - Glass composition versus PCCS prediction .................................................15

Table 14 - Product Consistency Test (PCT) …………….......................................................16

Table 15 - Hydrogen Generation in Similar Experiments ...................................................16

Table 16 - Plan for Additional Hydrogen Study ................................................................17

Table 17 - Hydrogen Generation during Additional Hydrogen Study ................................17 
Westinghouse Savannah River Company

Savannah River Technology Center
September 2, 1998

WSRC-RP-98-00149, Revision 1

\section{BACKGROUND}

The Defense Waste Processing Facility began processing radioactive Tank 51 Sludge in 1996. At the current processing rate, the Tank 51 sludge has been projected to be depleted as early as August 1998. After this time, DWPF will process a combination of the Tank 51 heel and the washed Tank 42 sludge after transfer to Tank 51 (sludge batch 1B).

Because the precipitate feed into DWPF was delayed three months, a sludge-only process was developed for Tank 51 sludge'. In Tank: Precipitation (ITP) startup delays led to the development of a more efficient, REDOX adjusted sludge-only flowsheet ${ }^{2,3}$ (REDOX is a measure of the slurry's reduction/oxidation potential). Both of these flowsheets were developed for Tank 51 (Sludge Batch $1 \mathrm{~A}$ ) only. Further testing is required to demonstrate a sludge-only process for Tank 42 (Sludge Batch

1B). This document details the testing performed in support of the Tank 42 sludge-only processing.

\section{INTRODUCTION}

To determine the processing parameters for the new sludge batch, several experiments were run at differing processing conditions. During the experiments, the process was monitored for problems such as foaming, excessive offgas deposits leading to plugging, and for target parameters, such as nitrite destruction and offgas composition and generation.

The objective of this testing was to complete a series of experiments (duplicating the expected SRAT and SME processing conditions in laboratory scale vessels) to supply the shielded cells with a set of processing parameters for their verification run. The important parameters that were determined include:

- The maximum hydrogen generation rate during each SRAT and SME processing cycle.

- The maximum nitrous oxide $\left(\mathrm{N}_{2} \mathrm{O}\right)$ generation rate during each SRAT and SME processing cycle.

- The minimum time necessary for completing the steam stripping of mercury to reach the $0.45 \mathrm{wt}$ $\%$ mercury limit in the SRAT product.

- The correct acid addition scheme necessary to produce a meter feed with a redox of $0.1-0.2$ $\mathrm{Fe}^{2+} / \mathrm{LFe}$.

- The acid stoichiometry necessary to achieve complete nitrite destruction in the SRAT (as"defined as the nitrite concentration less than $1000 \mathrm{ppm}$ ).

- The quality of the melter feed as measured by SME acceptability tests (PCCS and PCT). 


\section{DISCUSSION}

\section{EXPERIMENTAL}

\section{Method}

Six four-liter scale SRAT/SME processing nuns were completed in the 772-T lab at TNX. Each of the six runs consisted of a prototypic DWPF SRAT and SME cycle. The experimental setup was designed to volumetrically scale the DWPF vessels, flows, and feed-rates. For example, $1.8 \mathrm{~L}$ of sludge was used in each of the six runs. This is a scale factor of $1 / 11,360^{\text {th }}$ of DWPF scale based on a 6000 -gallon DWPF sludge batch. Thus the $2-$ gallon/minute acid addition rate was scaled down to $0.67 \mathrm{ml} / \mathrm{min}$. Appendix A contains a sketch of the experimental setup, the laboratory run plan and the scaled conditions used for these experiments.

The SRAT cycle includes all of the important DWPF processing steps as agreed to by DWPF Engineering and ITS. The SRAT cycle includes sludge preparation, sludge analysis, batching calculations, heat-up to $93^{\circ} \mathrm{C}$, addition of first nitric acid, then formic acid, heat-up to boiling, concentration down to 6000 gallons, then 12 hours of boiling. The key activities in the SRAT cycle include the neutralization of the sludge, reduction of various metals including manganese and mercury, and destruction of nitrite (defined as $<1000-\mathrm{ppm}$ nitrite ion left in solution). Key data includes hydrogen and $\mathrm{N}_{2} \mathrm{O}$ generation rates, nitrite destruction, and foaming likelihood.

The SME cycle includes the initial addition of a frit 200-water-formic acid slurry, boiling off water added with the frit-water-slurry, a second addition of a frit 200-water-formic acid slurry, boiling off water to reach a target solids loading of $45 \mathrm{wt} \%$ total solids, cool-down, and sampling. Key data includes hydrogen generation rate, glass quality, glass redox and foaming likelihood.

Table 1 compares the different parameters of each of the six runs.

Table I - Experimental Plan

\begin{tabular}{|c|c|c|c|c|}
\hline Run No. & Sludge- & Noble Metals & Redox Adjustment & Acid Target \\
\hline $1 \mathrm{~V}$ & 1B & $\begin{array}{c}\text { Prototypic Tank } \\
42+10 \%\end{array}$ & SME & $125 \%$ \\
\hline$\overline{2 V}$ & $\overline{I B}$ & $\begin{array}{c}\text { Prototypic Tank } \\
42+10 \%\end{array}$ & $\overline{\text { SRAT }}$ & $125 \%$ \\
\hline $3 V$ & IB & $\mathrm{HM}^{\top}$ & $\overline{\text { SRAT }}$ & $125 \%$ \\
\hline $4 V$ & IB & $\begin{array}{c}\text { Prototypic Tank } \\
42+10 \%\end{array}$ & $\overline{\text { SRAT }}$ & Maximum \\
\hline 5V & IB & $\begin{array}{c}\text { Prototypic Tank } \\
42+10 \%\end{array}$ & $\overline{\text { SRAT }}$ & $137.5 \%$ \\
\hline $6 \mathrm{~V}$ & IB & $\begin{array}{l}\text { Prototypic Tank } \\
42+10 \%\end{array}$ & $\overline{\text { SRAT }}$ & $125 \%$ \\
\hline
\end{tabular}

\footnotetext{
- IB refers to the sludge combination of Tanks 42 with the heel of Tank 51 which will be the next sludge batch that ${ }^{\prime}$ DWPF processes.

The HM rhodium concentration is approximately 7 times higher than the expected Tank 42 noble metal concentration.

- Maximum acid is an addition of a full tank of formic acid (480 gallons) to the SRAT.
} 
1V.The first batch was processed identically to the current DWPF sludge-only processing strategy. $125 \%$ of the stoichiometric acid is added in the SRAT. Some formic acid is added but not enough to produce an appropriate redox. After the SME cycle was complete, $90 \mathrm{wt} \%$ formic acid was added to increase the redox (as defined by the difference between formate concentration and nitrate concentration) $\mathrm{F}-\mathrm{N}=0.4 \mathrm{M}^{\S}$. The SME was boiled after the formio addition to determine the maximum hydrogen generation.

2V.The second batch was identical to the recommended redox adjusted sludge-only flowsheet the DWPF plans to implement in FY98. 125\% of the stoichiometric acid was added in the SRAT. Both $50 \mathrm{wt} \%$ nitric acid and $90 \mathrm{wt} \%$ formic acid were added to target a glass redox of 0.2 $\mathrm{Fe}^{2+} / \Sigma \mathrm{Fe}$. No formic acid was added to the SME to adjust the redox.

3V.The third batch was identical to $2 \mathrm{~V}$ except the DWPF design basis levels of noble metals and mercury were added to the sludge to create a bounding hydrogen generation rate.

4V.The fourth batch was also identical to $2 \mathrm{~V}$ except that enough formic acid was added to the SRAT to simulate the addition of the entire content of the formic acid feed tank to the SRAT. This experiment was designed represent the maximum credible deviation in the amount formic acid that could be added to the SRAT in a single addition during Tank 42 Sludge only processing.

5V.The fifth batch was also identical to $2 \mathrm{~V}$ except that $10 \%$ additional formic acid was added to the SRAT to ensure the nitrite was destroyed in the SRAT.

6V.The sixth batch was identical to $2 \mathrm{~V}$.

In all of the runs, the nitric and formic acids were fed at $93^{\circ} \mathrm{C}$. The SRAT contents were then heated to boiling and held there for at least 12 hours. In the case of the high mercury run (3V), the sludge was held at boiling longer in order to steam strip the mercury from the sludge. At the conclusion of the SRAT cycle, the SME cycle was commenced. Frit, water, and formic acid were added to the kettle in two installments. The SME cycle was considered over when the correct amount of water was collected to bring the kettle solids to 45-wt \%. During all of the runs, slurry $\mathrm{pH}$, offgas composition and inlet gas flow-rates were monitored online. Samples were pulled every two hours to monitor the nitrite, nitrate and formate ion concentrations in the slurry.

\section{Acid Addition Strategy}

Concentrated formic acid (90-wt \%) and nitric acid (50-wt\%) were used during processing. Total acid additions were based on total acid to achieve stoichiometry and an acid mix to produce a redox target $\left(0.1-0.2 \mathrm{Fe}^{2+} / \Sigma \mathrm{Fe}\right.$ redox ratio in the glass). Appendix B contains the calculations used to determine the acid additions for each nun. Dow corning 544 antifoam was added per the DWPF antifoam strategy (100 ppm on a total solution basis, 1 part antifoam: 19 parts water). An ammonia scrubber was also installed on the SRAT/SME vent stream.

5 The F-N number is the old description of the redox of the melter feed. Because the new redox adjustment method (based on the definition of redox as the ratio of $\mathrm{Fe}^{2+} / \mathrm{LFe}$ in the glass) has yet to be implemented, all redox numbers will be reported in both terms throughout this document. 


\section{Sludge Composition}

The sludge used in each of these runs contained approximately $16 \mathrm{wt} \%$ solids and represented the type of sludge that DWPF is expected to process. The sludge was prepared using a Tank 51 sludgesimulant (a nonradioactive simulant containing all the major sludge components except Uranium). The Tank 51 simulant was chosen because it is the sludge simulant closest to the Tank 42 composition. The Tank 51 simulant was doped with manganese, aluminum, and $\mathrm{SiO}_{2}$ since these components are significantly higher in the Tank 42 simulant. In addition, the rioble metals and mercury were added prior to each run as discussed in the previous section (10\% higher noble metals than Tank 42 concentration). The Tank 42 noble metals and mercury were significantly higher than Tank 51. The trimmed sludge $1 \mathrm{~B}$ simulant was then analyzed for solids, elementals, total base $(\mathrm{pH}$ 5.5) and density.

Table 2 - Sludge Properties Comparison

\begin{tabular}{|l|l|l|l|}
\hline \multicolumn{2}{|c}{ Batch 1B } & \multicolumn{1}{c|}{$\begin{array}{c}\text { Tank 42 } \\
\text { (before storage) }\end{array}$} & \multicolumn{1}{c|}{$\begin{array}{c}\text { Tank } 4 \text { years of storage) } \\
\text { yearter 2 }\end{array}$} \\
\hline Total solids (wt \%) & 16.26 & 16.03 & 15.00 \\
\hline Specific gravity & 1.13 & 1.123 & 1.113 \\
\hline
\end{tabular}


Westinghouse Savannah River Company Savannah River Technology Center

Table 3 - Sludge Composition Comparison

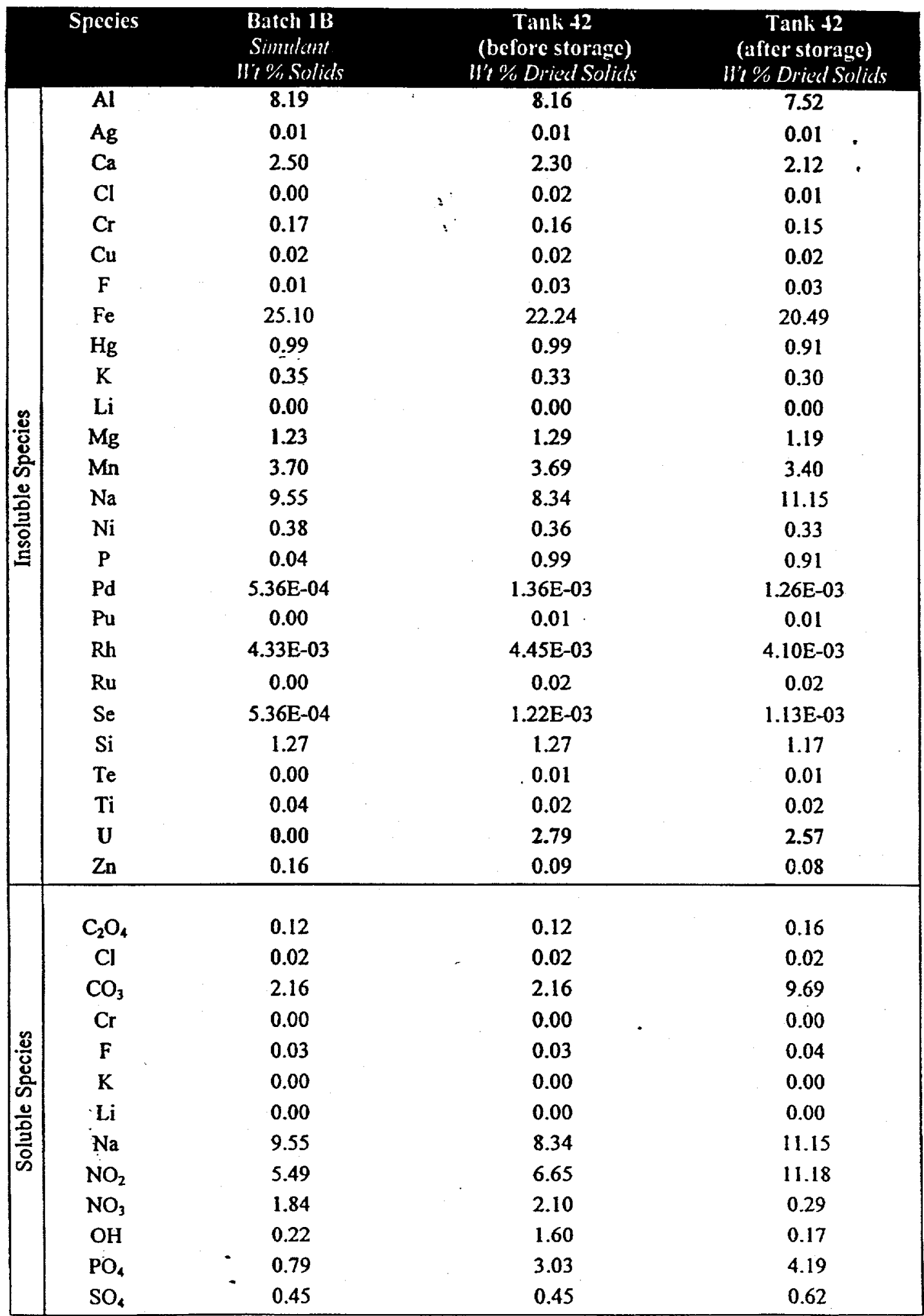




\section{Frit Addition Strategy}

Two equal additions of frit 200 , water and formic acid were designed to duplicate the frit slurry that is transferred into the SME. No water was added to simulate the addition of Frit-decon water to the SME. The frit 200 was added dry through a funnel to the kettle, followed by the addition of 90 -weight percent formic acid, and then water. The addition of frit was predicted by PCCS based on the SRAT solids quantity remaining at the completion of the SRAT cycle. PCCS was based on the SRAT receipt sample that was analyzed once for all the experiments.

\section{RESULTS}

\section{Nitrite Destruction}

The DWPF Chemical Process Cell hydrogen flammability control system is comprised of control air purges to the SRAT and SME to dilute the concentration of the hydrogen that is generated. In addition, the hydrogen concentration is monitored to prevent the formation of a flammable mixture. The maximum hydrogen generation rate (design basis) was determined in previous experiments to be $0.65 \mathrm{lbs} / \mathrm{hr}$ and $0.23 \mathrm{lbs} / \mathrm{hr}$ for the SRAT and SME respectively). ${ }^{4}$

Nitrite destruction is believed to be necessary for the generation of hydrogen during SRAT and SME processing. The sludge has approximately $8,000 \mathrm{mg} / \mathrm{L}$ of nitrite in the SRAT feed and the nitrite must be destroyed " during the twelve hour boiling phase in the SRAT to produce the maximum hydrogen. This twelve hour boiling time is consistent with the recommendation in the Tank 51 processing ${ }^{5}$. The more acid added the faster the nitrite destruction.

The nitrite destruction is summarized in Table 5 and Figure 1. When 125\% of the stoichiometric acid was added and Tank 42 level noble metals were present in the sludge (runs $1 \mathrm{~V}, 2 \mathrm{~V}$, and $6 \mathrm{~V}$ ), the nitrite was not sufficiently destroyed during the twelve hours of boiling. When $125 \%$ of the stoichiometric acid was added and HM levels of noble metals were present in the sludge (run 3V), the nitrite was sufficiently destroyed during the twelve hours of boiling. When $137.5 \%$ or more of the stoichiometric acid was added and Tank 42 level noble metals were present in the sludge (runs $4 \mathrm{~V}$ and $5 \mathrm{~V})$, the nitrite was sufficiently destroyed during the twelve hours of boiling.

\footnotetext{
" Nitrite destruction has been defined previously as $<1000 \mathrm{ppm}$ in solution but ghis is difficult to measure in ...
} 
Table 4 - Tank 42 SRAT Product Nitrite Concentration

\begin{tabular}{l} 
Run \\
\multicolumn{3}{|c|}{ Nitrite } & \multicolumn{1}{c|}{ Acid } & Noble Mletals \\
\begin{tabular}{|l|r|r|c|}
\hline Run 1V & 1,703 & $125 \%$ & Tank 42 \\
\hline Run 2V & 1,879 & $125 \%$ & Tank.42 \\
\hline Run 3V & 200 & $125 \%$ & HM \\
\hline Run 4V & 1 & $>137.5 \%$ & Tank 42 \\
\hline Run 5V & 111 & $137.5 \%$ & Tank 42 \\
\hline Run 6V & 1,288 & $125 \%$ & Tank 42 \\
\hline
\end{tabular}
\end{tabular}

Recommendation: Based on this testing, the addition of $137.5 \%$ of the stoichiometrically required acid will ensure the nitrite is sufficiently destroyed during the twelve hour boiling period. This is $10 \%$ higher than had been recommended by the Tank 51 Alternative Sludge Only Flowsheet.

Figure 1 - Nitrite Destruction

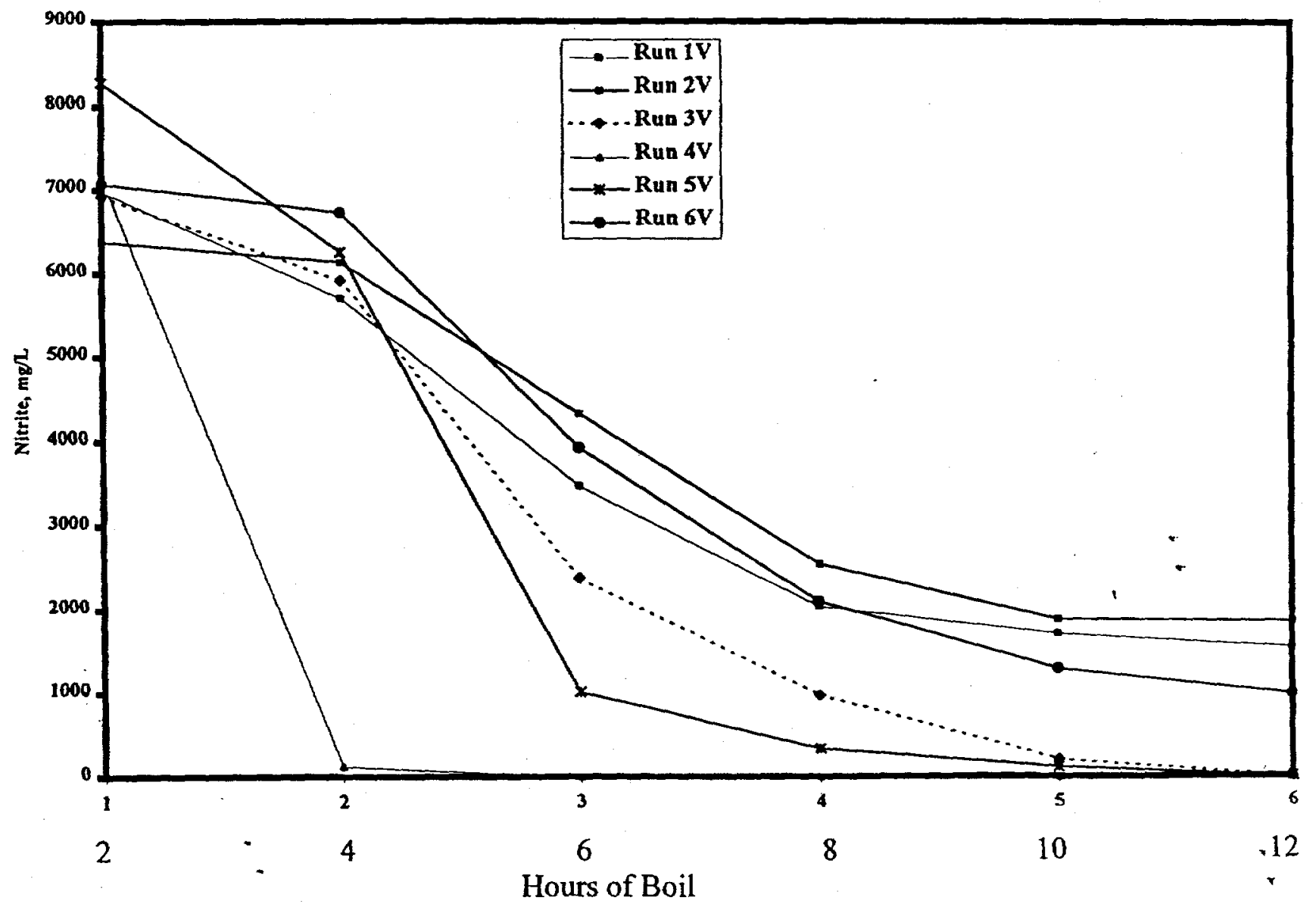




\section{Offgas Composition}

The offgas was monitored to compositionally characterize the offgas. An internal helium standard was used to calculate the outlet flow ${ }^{\text {tt }}$. The offgas was monitored using a Gas Chromatograph. Figure 2 shows the hydrogen generation rate during each of the six SRAT cycles. Figure 3 shows the hydrogen generation rate during each of the six SME cycles. The flow rates reported were scaled to a 6000 gallon DWPF batch. The highest amount of hydrogen occurred in the run where excess formic acid was added, run $4 \mathrm{~V}$. The second highest peak occurred in run $3 \mathrm{~V}$, the run in which $\mathrm{HM}$ levels of noble metals were added. Note also that the hydrogen peak occurred in the SME in all runs except run $4 \mathrm{~V}$.

The maximum hydrogen generation occurred in the two extreme runs, 3V (HM levels of noble metals) and $4 \mathrm{~V}$ (maximum acid addition). The maximum peak observed during processing corresponds to a rate of $0.31 \mathrm{lbs} / \mathrm{hr}$ in the DWPF SRAT during run $3 \mathrm{~V}$ and $0.17 \mathrm{lbs} / \mathrm{hr}$ in the DWPF SME during run 4V. The upper limits in the SRAT and SME are $0.65 \mathrm{lbs} / \mathrm{hr}$ and $0.23 \mathrm{lbs} / \mathrm{hr}$ respectively. Table 6 shows the peak hydrogen generation rate in each of the 6 runs.

The hydrogen generation was very low in runs with Tank 42 level noble metals and normal (125\%) acid addition. In these runs the maximum hydrogen in the SRAT was $0.01 \mathrm{lb} / \mathrm{hr}$ in the SRAT and $0.085 \mathrm{lb} / \mathrm{hr}$ in the SME.

Because of incomplete destruction of nitrite during the SRAT cycle in Run 2V and the extremely low hydrogen generation, Run $2 \mathrm{~V}$ was duplicated to ensure that nitrite could be adequately destroyed and conservative hydrogen generation rates were determined. First, run $2 \mathrm{~V}$ was repeated with $10 \%$ additional acid (137.5\% versus $125 \%$ ). In run $5 \mathrm{~V}$, nitrite was destroyed in the SRAT and a higher hydrogen generation rate was calculated. In run $6 \mathrm{~V}$, designed to duplicate $2 \mathrm{~V}$, nitrite was not completely destroyed in the SRAT and a lower hydrogen generation rate was calculated.

\section{Table 5 - Hydrogen Generation Summary (DWPF Basis)}

\begin{tabular}{|c|c|c|c|c|c|c|}
\hline \multirow[b]{2}{*}{ Description ${ }^{* \neq}$} & \multicolumn{6}{|c|}{ Experinient } \\
\hline & IV & $2 \mathrm{~V}$ & $3 V$ & AV & $\mathbf{5 Y}$ & $6 V$ \\
\hline Noble Metals & 42 & 42 & An & 42 & 42 & 42 \\
\hline Redox Adjustment & SME & $\overline{\text { SRAT }}$ & SRAT & $\overline{N A}$ & SRAT & SRAT \\
\hline Acid & $125 \%$ & $125 \%$ & $125 \%$ & $254 \%$ & $137.5 \%$ & $125 \%$ \\
\hline Max SRAT H & $0.010 \mathrm{lb} / \mathrm{hr}$ & $0.001 \mathrm{lb} / \mathrm{hr}$ & $0.104 \mathrm{lb} / \mathrm{hr}$ & 0370167 & $0.004 \mathrm{lb} / \mathrm{hr}$ & $0.001 \mathrm{lb} / \mathrm{hr}$ \\
\hline Max SME H & $0.059 \mathrm{lb} / \mathrm{hr}$ & $0.000 \mathrm{lb} / \mathrm{hr}$ & 0.6796h & $0.162 \mathrm{lb} / \mathrm{hr}$ & $0.085 \mathrm{lb} / \mathrm{hr}$ & $0.012 \mathrm{lb} / \mathrm{hr}$ \\
\hline Max $\mathrm{H}_{2}$ Concentration & 0.158 vol $\%$ & 0.001 vol \% & $0.368 \mathrm{vol} \%$ & 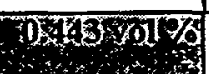 & 0.005 vol \% & 0.001 vol $\%$ \\
\hline
\end{tabular}

"A known rate of helium was added to the inlet air stream to the SRAT. The outlet gas flow was monitored for helium. The total outlet flow was calculated based on the dilution of the helium by air and other generated gases.

It DWPF limits in parentheses 
Westinghouse Savannah River Company

Savannah River Technology Center

September 2, 1998

WSRC-RP-98-00149, Revision 1

Figure 2 - SRAT Cycle Hydrogen Generation

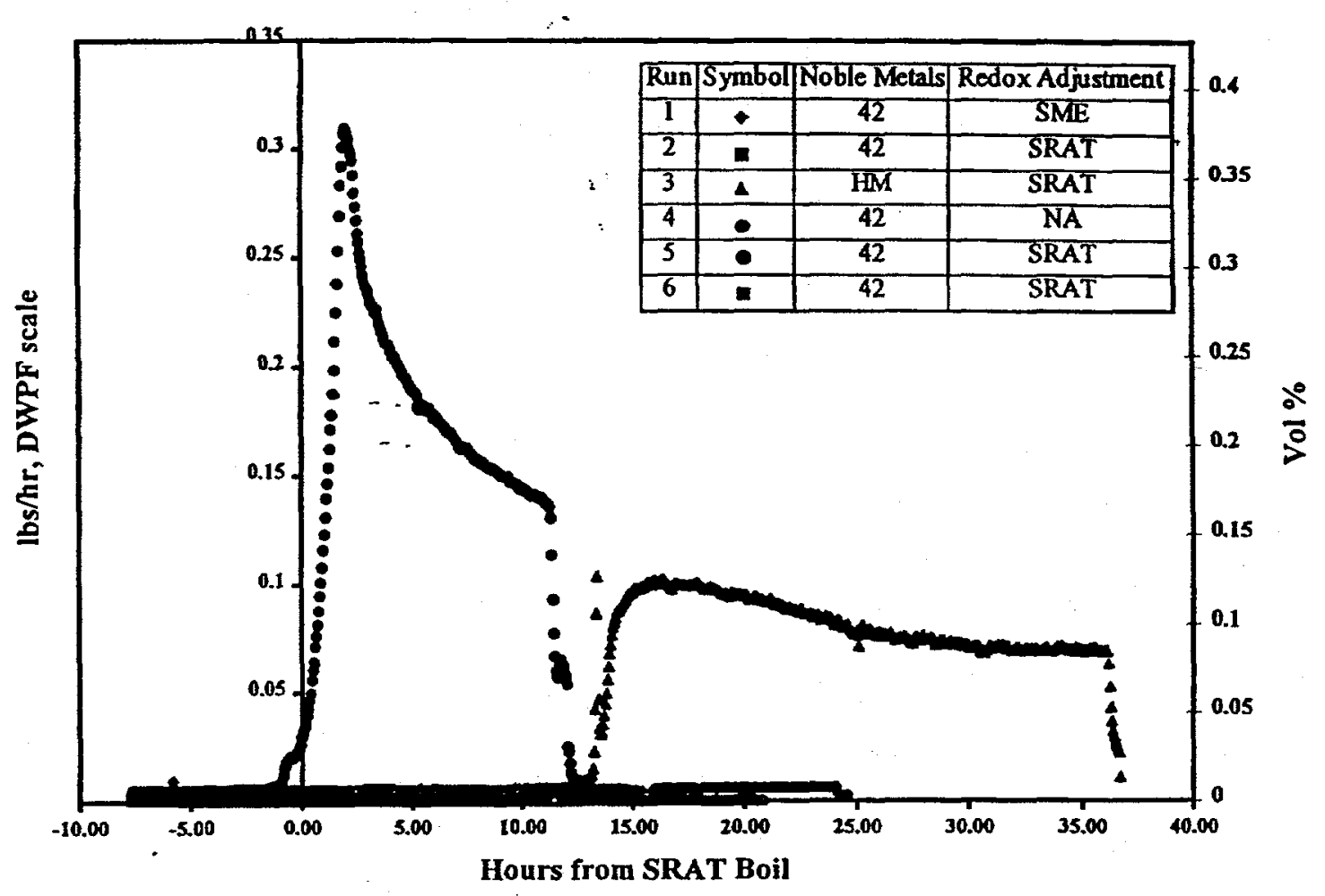


Westinghouse Savannah River Company

Savannah River Technology Center
September 2, 1998

WSRC-RP-98-00149, Revision 1

Figure 3 - SME Cycle Hydrogen Generation

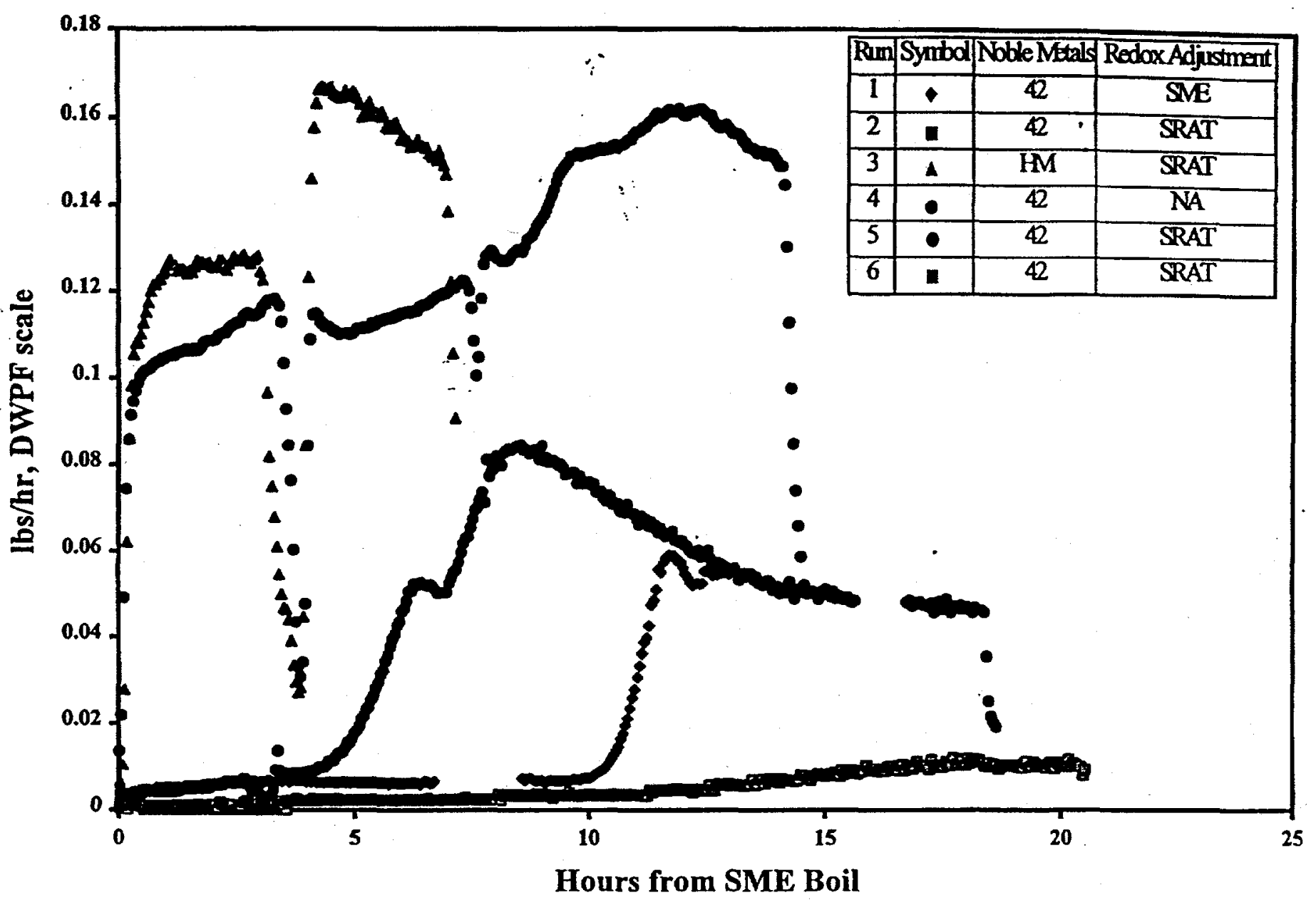

The maximum $\mathrm{N}_{2} \mathrm{O}$ generation rate was $77.7 \mathrm{lb} / \mathrm{hr}$ which resulted in a $\mathrm{N}_{2} \mathrm{O}$ concentration of 3.85 volume \% in the SRAT cycle of Run $4 \mathrm{~V}$. This concentration is well below the 20 -volume $\%$ basis for DWPF flammability calculations. There was no measured $\mathrm{N}_{2} \mathrm{O}$ in the SME cycle during any of the runs. Table 7 summarizes the $\mathrm{N}_{2} \mathrm{O}$ generation rate and volume \% in each of the 6 runs. 
Table 6 - Nitrous Oxide Summary

\begin{tabular}{|c|c|c|c|c|c|c|}
\hline \multirow[b]{2}{*}{ Description $\$$} & \multicolumn{6}{|c|}{ Experiment } \\
\hline & IV & $2 \mathrm{~V}$ & $3 V$ & $4 V$ & $5 V$ & $6 Y$ \\
\hline Noble Metals & 42 & 42 & Wחy & 42 & 42 & 42 \\
\hline Redox Adjustment & SME & $\overline{\text { SRAT }}$ & SRAT & $\overline{N A}$ & SRAT & $\overline{\text { SRAT }}$ \\
\hline Acid & $125 \%$ & $125 \%$ & $125 \%$ & Thestint & $137.5 \%$ & $125 \%$ \\
\hline Max SRAT $\mathrm{N}_{2} \mathrm{O}$ & $23.802 \mathrm{Ib} / \mathrm{hr}$ & $5.411 \mathrm{lb} / \mathrm{hr}$ & $21.228 \mathrm{lb} / \mathrm{hr}$ & $74,66 \mathrm{bm}$ & $45.102 \mathrm{lb} / \mathrm{hr}$ & $23.152 \mathrm{lb} / \mathrm{hr}$ \\
\hline Max SME N2O & $0.000 \mathrm{lb} / \mathrm{hr}$ & $0.000 \mathrm{lb} / \mathrm{hr}$ & $0.000 \mathrm{lb} / \mathrm{hr}$ & $0.000 \mathrm{lb} / \mathrm{hr}$ & $0.000 \mathrm{lb} / \mathrm{hr}$ & $0.000 \mathrm{lb} / \mathrm{hr}$ \\
\hline $\operatorname{Max} \mathrm{N}_{2} \mathrm{O}(<20 \%)$ & $1.258 \mathrm{vol} \%$ & $0.204 \mathrm{vol} \%$ & $1.097 \mathrm{vol} \%$ & $80 \%$ & $2.442 \mathrm{vol} \%$ & $1.009 \mathrm{vol} \%$ \\
\hline
\end{tabular}

\section{Steam Stripping}

The mercury concentration in the SRAT product must be below $0.45 \mathrm{wt} \%$ mercury (design basis) to minimize corrosion in the melter offgas piping and minimize the mercury emission to the environment. Mercury is present as mercuric oxide $(\mathrm{HgO})$ in the sludge. Mercuric oxide must be reduced to elemental mercury by formic acid (the reductant). The elemental mercury is then removed from the sludge by steam stripping during the boiling phase in the SRAT. The mercury is collected and accumulates in the Mercury Water Wash Tank (MWWT). The mercury in Tank 42 sludge is approximately $1.0 \mathrm{wt} \%$ in the sludge solids. It requires approximately 6.9 hours of boiling at a steam flowrate of $5000 \mathrm{lb} / \mathrm{hr}$ to strip enough mercury from the SRAT to meet the $0.45 \mathrm{wt} \%$ SRAT product goal with Tank 42 sludge and 35.9 hours of boiling in batch $3 \mathrm{~V}$ where HM levels of mercury were added. Note this is based on the assumption that 750 pounds of steam are required to remove one pound of mercury. It also assumes complete separation of mercury in the MWWT. Table 8 summarizes the mercury in the SRAT product for the six runs.

\section{Table 7 - SRAT Product Mercury Concentration}

\begin{tabular}{|c|c|c|}
\hline Run & Mercury, ppm & Mereury, wt \% \\
\hline 1V & 101 & 0.051 \\
\hline 2V & 139.7 & 0.070 \\
\hline 3V & $1457 / 1568$ & $0.73 / 0.79$ \\
\hline 4V & 29.6 & 0.015 \\
\hline 5V & 60.3 & 0.030 \\
\hline 6V & 105.0 & 0.053 \\
\hline
\end{tabular}

All runs except the high (HM) mercury and noble metal run met the mercury target of 0.45 wt\%. A longer stripping time may be required for high mercury sludge but the twelve-hour SRAT boil is sufficient for the Tank 42 sludge. The SRAT product from Run $3 \mathrm{~V}$ was reanalyzed to confirm the : high mercury content.

${ }^{56} \mathrm{DWPF}$ limits in parentheses 
Westinghouse Savannah River Company

Savannah River Technology Center

Acid Additions and Redox Targets
September 2, 1998

WSRC-RP-98-00149, Revision 1

Kevin Brown, SRTCATS, developed a spreadsheet to calculate the nitric and formic acid addition to reach a redox target for each run. The calculation for each of the runs is summarized below in Table 9. The details of the calculations are summarized in Appendix B.

\section{Table 8 - Acid Addition and Redox Target \\ $\because$}

\begin{tabular}{|c|c|c|c|c|c|c|}
\hline & \multicolumn{6}{|c|}{ Experiment } \\
\hline Description & iv & $2 \mathrm{~V}$ & $3 \mathrm{~V}$ & $4 \mathrm{~V}$ & $5 \mathrm{~V}$ & $6 \mathrm{~V}$ \\
\hline Noble Metals & 42 & $\overline{42}$ & $\overline{\mathrm{HM}}$ & $\overline{42}$ & 42 & $\overline{42}$ \\
\hline Redox Adjustment & SMTE & SRAT & SRAT & $\overline{\mathrm{NA}}$ & SRAT & SRAT \\
\hline Redox Target $\left(\mathrm{Fe}^{+2} \sqrt{\mathrm{LFe}}\right)$ & None & 0.20 & 0.20 & None & 0.20 & 0.20 \\
\hline Acid Target & $125 \%$ & $125 \%$ & $125 \%$ & $254 \%$ & $137.5 \%$ & $125 \%$ \\
\hline$\overline{\text { Batch Size }}$ & 6000 gallons & 6000 gallons & 6000 gallons & 6000 gallons & 6000 gallons & 6000 gallons \\
\hline 90 wt \% Formic Acid & $171.2 \mathrm{gal}$ & $212.6 \mathrm{gal}$ & $219.1 \mathrm{gal}$ & $480.0 \mathrm{gal}$ & $229.6 \mathrm{gal}$ & $210.4 \mathrm{gal}$ \\
\hline 50 wt \% Nitric Acid & $200.0 \mathrm{gal}$ & 106.8 & $107.6 \mathrm{gal}$ & $106.8 \mathrm{gal}$ & $119.7 \mathrm{gal}$ & $105.0 \mathrm{gal}$ \\
\hline
\end{tabular}

The glass redox (reduction/oxidation potential) was measured for the first four experiments by the SRTC Mobile lab. The results are summarized in Table 10 (reporting redox as F-N as DWPF does currently) and Table 11 (reporting redox as $\mathrm{Fe}^{+2} / \Sigma \mathrm{Fe}$, a better measure of redox than $\mathrm{F}-\mathrm{N}$ ). Table 10 summarizes the redox (F-N) data for the first four experiments. The F-N (difference between the Formate and Nitrate Molar concentrations) was calculated for each of these runs based on the Formate and Nitrate analyses corrected for a $45-\mathrm{wt} \%$ slurry. Table 11 summarizes the redox $\left(\mathrm{Fe}^{+2} / \Sigma \mathrm{Fe}\right)$ data for the first four experiments. The "Target Redox" column was based on the redox target as input into the Kevin Brown spreadsheet. The "Calculated Redox" column was a calculation of the redox based on the Kevin Brown redox correlation ${ }^{6}$. The "measured redox" column was the redox as measured by the SRTC Mobile Lab of glasses vitrified by Alex Cozzi.

The measured redox for the first three experiments was very oxidizing. This is much lower than had been targeted for Runs $2 \mathrm{~V}$ and $3 \mathrm{~V}$. It should be noted that it is very difficult to vitrify and measure the redox of the resulting glass without overly oxidizing the glass. It is believed that the actual glass produced in the DWPF melter should be much more reducing than the glasses that were analyzed by the SRTC Mobile Lab. Note that in glasses made in sludge only testing, higher redox measurements have been achieved only in glass produced in the 774-A melter run with Tank 51 sludge? 
Table 9 - Predicted versus Actual Redox (F-N) of Melter Feeds

\begin{tabular}{|c|c|c|}
\hline \multicolumn{3}{|c|}{ Calculated F-N } \\
Run & Mobile Lab & TNX \\
\hline 1V & 0.33 & 0.19 \\
\hline 2V & 0.62 & 0.58 \\
\hline 3V & 0.35 & 0.35 \\
\hline 4V & $: 0.99$ & 1.26 \\
\hline
\end{tabular}

Table 10 - Predicted versus Actual Redox $\left(\mathrm{Fe}^{+2} \sqrt{\Sigma \mathrm{Fe}}\right)$ of Melter Feeds

\begin{tabular}{|c|c|c|c|c|}
\hline Redox & $\begin{array}{c}\text { Target } \\
\text { Based on Melted Feed } \\
\text { Formate and Nitrate } \\
\text { SRTC Mobile Lab TNX }\end{array}$ & $\begin{array}{c}\text { Measured } \\
\text { Redox }\end{array}$ \\
Run & \multicolumn{4}{c|}{ SRTC M } \\
\hline 1V & $<0.03$ & 0.03 & 0.03 & $<0.03$ \\
\hline 2V & 0.20 & 0.23 & 0.22 & $<0.03$ \\
\hline 3V & 0.20 & 0.18 & 0.20 & $<0.03$ \\
\hline 4V & 0.45 & 0.33 & 0.39 & 0.36 \\
\hline
\end{tabular}

\section{SME Product Acceptability Tests}

Product Composition Control System (PCCS) Acceptability

The SME products were vitrified in alumina crucibles by Alex Cozzi and Pat Toole. The SRTC Mobile Lab completed the elemental analyses to verify that the process produced quality glass quality glass. The glass elemental analysis was entered into PCCS acceptance spreadsheet (PCCS Version 3.2, appendix B). The SME products passed all but two of the PCCS acceptability tests. The two PCCS acceptability tests that failed were viscosity and liquidus, both DWPF processability constraints. Note that these glasses failed the Liquidus Temperature and High Viscosity Constraint at a 95\% confidence level.

The probable explanation for failing to meet all PCCS acceptability constraints was that frit was underadded to the sludge because the glass was lower in frit components ( $\mathrm{Li}$ and $\mathrm{B}$ ) than had been predicted by PCCS. Also, some of the sludge components were higher than expected (Al, Mn). However, the major glass components ( $\mathrm{Fe}, \mathrm{Si}, \mathrm{Na}$ ) were very close to the $\mathrm{PCCS}$ prediction. In addition, the ratio of key sludge components (such as $\mathrm{Fe} / \mathrm{Al}$ ) was different in the glass than it was in the sludge suggesting that $\mathrm{Fe}$ was lost during testing or the $\mathrm{Al}$ analysis in the sludge was low.

One way to understand what may have caused the failure of the test is to look at the ratio of the measured glass composition to the expected glass composition. The expected glass composition was predicted by PCCS based on the sludge sample. If frit was over-added, the frit components $(\mathrm{Si}, \mathrm{Li}$, 
and $\mathrm{B}$ ) will be higher than predicted. If sludge was over-added, the sludge components (Fe, $\mathrm{Al}, \mathrm{Mn}$, $\mathrm{Mg}, \mathrm{Ca}$, and $\mathrm{Na}$ ) will be higher than predicted. Note that many of the sludge ratios are greater than 1 and many of the frit ratios are $<1$, suggesting that frit was under-added. However, the iron and silicon ratios are approximately 1 as expected (iron and silicon oxides are the major components in the sludge). The results of the PCCS acceptability tests are summarized in Table 12.

\section{Table 11 - PCCS Acceptability Data}

\section{Passed PCCS Acceptance version 2.5?}

\begin{tabular}{|c|c|c|c|c|}
\hline Criteria & $1 V$ & $2 V$ & $3 V$ & $4 V$ \\
\hline B Leaching & Yes & Yes & Yes & Yes \\
\hline Li Leaching & Yes & Yes & Yes & Yes \\
\hline Na Leaching & Yes & Yes & Yes & Yes \\
\hline Liquidus Temp & No & No & No & No \\
\hline High Viscosity & No & No & No & No \\
\hline Low Viscosity & Yes & Yes & Yes & Yes \\
\hline Homogeneity & Yes & Yes & Yes & Yes \\
\hline $\mathrm{Al}_{2} \mathrm{O}_{3}$ & Yes & Yes & Yes & Yes \\
\hline High Conserve & Yes & Yes & Yes & Yes \\
\hline Low Conserve & Yes & Yes & Yes & Yes \\
\hline Low Frit & Yes & Yes & Yes & Yes \\
\hline High Frit & Yes & Yes & Yes & Yes \\
\hline TiO2 & Yes & Yes & Yes & Yes \\
\hline $\mathrm{NaCl}$ & Yes & Yes & Yes & Yes \\
\hline NaF & Yes & Yes & Yes & Yes \\
\hline $\mathrm{Cr}_{2} \mathrm{O}_{3}$ & Yes & Yes & Yes & Yes \\
\hline $\mathrm{Na}_{2} \mathrm{SO}_{4}$ & Yes & Yes & Yes & Yes \\
\hline $\mathrm{Cu}$ & Yes & Yes & Yes & Yes \\
\hline $\mathrm{P}_{2} \mathrm{O}_{5}$ & Yes & Yes & Yes & Yes \\
\hline
\end{tabular}

An analysis of the data indicated that an over-addition of frit might have led to the high viscosity and liquidus. The $\mathrm{Li}$ and $\mathrm{B}$ concentrations in the glass were higher than predicted (compared to the initial PCCS prediction based on the sludge analysis). In addition, many of the sludge components, including aluminum, calcium and manganese were lower than predicted. The major components in the glass (>1 wt \%) are summarized in Table 13. 
Table 12 - Glass composition versus PCCS prediction

\begin{tabular}{|r|c|c|c|}
$\begin{array}{c}\text { Sludge } \\
\text { Component }\end{array}$ & $\begin{array}{c}\text { PCCS Expected, } \\
\text { wt \% }\end{array}$ & Actual, wt \% & $\begin{array}{c}\text { Ratio, } \\
\text { Actual/Expected }\end{array}$ \\
\hline Al & 2.65 & 3.16 & 1.19 \\
\hline $\mathrm{Ca}$ & 0.98 & 1.21 & 1.24 \\
\hline $\mathrm{Fe}$ & 8.46 & 8.63 & 1.02 \\
\hline $\mathrm{Mg}$ & 1.28 & 1.26 & 0.98 \\
\hline $\mathrm{Mn}$ & 1.10 & 1.22 & 1.11 \\
\hline $\mathrm{Na}$ & 8.73 & 8.34 & 0.96 \\
\hline $\begin{array}{r}\text { Frit } \\
\text { Component }\end{array}$ & $\begin{array}{r}\text { PCCS Expected, } \\
\text { wt \% }\end{array}$ & Actual, wt \% & $\begin{array}{c}\text { Ratio, } \\
\text { Actual/Expected }\end{array}$ \\
\hline $\mathrm{B}$ & 2.77 & & 0.81 \\
\hline $\mathrm{Li}$ & 1.72 & 2.26 & 0.85 \\
\hline Si & 24.75 & 1.47 & 1.01 \\
\hline
\end{tabular}

However, another explanation for failing to meet the PCCS acceptance criteria is there could have been an error in the sludge composition or the glass composition. Since the only source of iron and aluminum is from the sludge, the ratio of iron to aluminum (Fe/Al) should be the same in the sludge and the glass. However, the ratio of $\mathrm{Fe} / \mathrm{Al}$ was 3.19 in the sludge versus 2.81 in the glass suggesting there was $10 \%$ more aluminum than had been predicted based on the sludge receipt sample. Future testing should be done with the SRAT product sample instead of the sludge receipt sample (consistent with DWPF practice) to minimize the error in calculating the frit addition.

Product Consistency Test (PCT) Acceptability

The glasses produced from each of the first four experiments were tested using the ASTM C1285 (Product Consistency Test, PCT) protocol to determine the seven day normalized release for $\mathrm{Na}, \mathrm{Li}, \mathrm{K}$, $\mathrm{B}$, and $\mathrm{Si}$ versus the EA Glass Standard ${ }^{8}$. The normalized release values for these cations is significantly"* lower than the EA Glass Standard.

The PCT results (average of three analyses) are summarized in Table 14. Glass compositions and complete PCT results are tabulated in Appendix C. The table in Appendix C shows that the bind multi-element standard for the element $\mathrm{Na}$ was not in control, e.g. $>10 \%$ difference between the standard and the value reported. Therefore, the PCT procedure does not permit reporting/usage of the $\mathrm{Na}$ values. It should also be noted that for the B results from the 7-day PCT shown in Table 14 are in excellent agreement with the B release predicted by PCCS (Table C-1, Appendix C), e.g. $0.56 \mathrm{~g} / \mathrm{L}$ predicted vs. $0.59,0.56,0.62,0.61 \mathrm{~g} / \mathrm{L}$ measured (Table 14).

\footnotetext{
".* Normalized boron release values for the PCT are less than two standard deviations of the variability of EA glass.
} 
Table 13 - Product Consistency Test (PCT)

Average Normalized Release

\begin{tabular}{|c|c|c|c|c|c|}
\hline \multicolumn{6}{|c|}{ Glass $B \quad$ Si $\quad N a \quad L i \quad K$} \\
\hline & $g / L$ & & & $\mathrm{~g} / \mathrm{L}$ & $\mathrm{g} / \mathrm{L}$ \\
\hline ARM & 0.59 & 0.32 & \# & 0.68 & N/A \\
\hline TIV & 0.56 & 0.33 & \# & 0.63 & $\overline{N / A}$ \\
\hline $\mathrm{T} 2 \mathrm{~V}$ & 0.62 & 0.38 & $\#$ & 0.66 & N/A \\
\hline T3V & 0.61 & 0.35 & \#\# & 0.65 & N/A \\
\hline$\overline{T A V}$ & 0.84 & 0.39 & 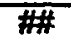 & 0.69 & N/A \\
\hline$\overline{E A}$ & 15.03 & 3.96 & \# & 7.91 & 2.59 \\
\hline
\end{tabular}

\#\# Measurements of $\mathrm{Na}$ in the multi-element solution standard were not in the acceptable range to permit reporting data.

\section{Additional Hydrogen Testing}

Additional hydrogen testing was completed because there was higher hydrogen production in the run with more nitric acid (1V) than the runs with less nitric acid (runs $2 \mathrm{~V}$ and 6V). Two additional SRAT/SME cycles (Runs $5 \mathrm{~V}$ and $6 \mathrm{~V}$ ) were added in an attempt to understand the lower hydrogen generation in Run 2V compared with Run 1V. Run 6V was a duplicate of $2 \mathrm{~V}$. Run $5 \mathrm{~V}$ was similar to Run 2V, except that an additional $10 \%$ acid was added. Extra acid was added because it appeared that inadequate acid had been added during experiments $1 \mathrm{~V}$ and $2 \mathrm{~V}$ (nitrite was not completely destroyed). Table 15 summarizes the results of these similar experiments.

\section{Table 14 - Hydrogen Generation in Similar Experiments}

\begin{tabular}{|l|c|c|c|c|}
\hline & \multicolumn{2}{c}{ Original Experiments } & \multicolumn{2}{c|}{ Additional Experiments } \\
\hline & IV & $2 \mathrm{~V}$ & $5 \mathrm{~V}$ & $6 \mathrm{~V}$ \\
\hline Nobcription ${ }^{4 \hat{*}}$ & 42 & 42 & 42 & 42 \\
\hline Acid Mix & More Nitric & More Formic & More Formic & More Formic \\
\hline Acid & $125 \%$ & $125 \%$ & $137.5 \%$ & $125 \%$ \\
\hline Max SRAT $\mathrm{H}_{2}(<0.65)$ & $0.010 \mathrm{lb} / \mathrm{hr}$ & $0.001 \mathrm{lb} / \mathrm{hr}$ & $0.004 \mathrm{lb} / \mathrm{hr}$ & $0.001 \mathrm{lb} / \mathrm{hr}$ \\
\hline Max SME $\mathrm{H}_{2}(<0.23)$ & $0.059 \mathrm{lb} / \mathrm{hr}$ & $0.000 \mathrm{lb} / \mathrm{hr}$ & $0.085 \mathrm{lb} / \mathrm{hr}$ & $0.012 \mathrm{lb} / \mathrm{hr}$ \\
\hline
\end{tabular}

Based on the two additional experiments, it is apparent that the hydrogen generation in Run $2 \mathrm{~V}$ and $6 \mathrm{~V}$ led to a minimal hydrogen production in both the SRAT and SME cycle. This hydrogen generation is much less than Run $1 \mathrm{~V}$.

In an attempt to understand why the experiments with less nitric acid led to lower hydrogen generation, eight additional hydrogen study experiments were completed. The experiments were all completed using the same melter feed, a combination prepared by combining the melter feed from :

TIt DWPF limits in parentheses, Hydrogen generation calculated based on a 6000 gallon DWPF Batch. 
Westinghouse Savannah River Company

Savannah River Technology Center

September 2, 1998

WSRC-RP-98-00149, Revision 1

Runs $5 \mathrm{~V}$ and $6 \mathrm{~V}$. These melter feeds were chosen because they were relatively low in hydrogen generation.

At the beginning of each experiment, $250 \mathrm{ml}$ of melter feed was added to a one-liter kettle. Next, the appropriate acid was added to the agitated mixture using an autotitrator. The mixture was heated to boiling and maintained at boiling for four hours. An air purge with an internal helium standard was used to measure the hydrogen generation. The conditions for the eight additional runs are summarized in Table 16.

Table 15 - Plan for Additional Hydrogen Study

\begin{tabular}{|c|c|c|}
\hline Run & Added Acid M & Acid \\
\hline $11 \mathrm{C}$ & $0.00 \mathrm{M}$ & none \\
\hline $12{ }_{12}$ & 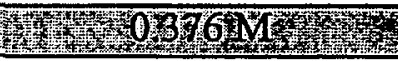 & 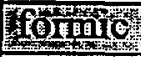 \\
\hline $13 \mathrm{C}$ & $0.752 \mathrm{M}$ & formic \\
\hline 194 & W & mithe \\
\hline 15. & 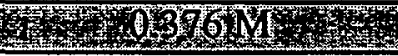 & 19010 \\
\hline $16 \mathrm{C}$ & $0.188 \mathrm{M}$ & formic \\
\hline $17 \mathrm{C}$ & $0.094 \mathrm{M}$ & formic \\
\hline $18 \mathrm{c}$ & 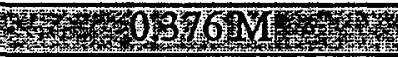 & Toing \\
\hline
\end{tabular}

The results of the experiments are summarized in Table 17. Note that four of the runs (shaded in Table 16 and 17) were completed with the addition of 0.376 moles of formic, nitric or hydrochloric acid (planned to raise acidity by $0.376 \mathrm{M}$ ). The runs with added formic acid had much higher hydrogen generation than the runs with the addition of strong acids, nitric and hydrochloric acid. This is the opposite of the trend noted in the variability runs. Note also that the measured acidity of the melter feed after the addition of the acid was less than had been predicted. As a result of the inconsistent data collected during this experimentation, additional experiments are recommended to study the generation of hydrogen during SRAT and SME cycles.

Table 16 - Hydrogen Generation during Additional Hydrogen Study

\begin{tabular}{|c|c|c|c|c|c|c|c|c|}
\hline Run & $11 \mathrm{C}$ & $17 \mathrm{C}$ & $16 \mathrm{C}$ & $12 C$ & $18 \mathrm{C}$ & $13 \mathrm{C}$ & $14 C$ & $15 \mathrm{C}$ \\
\hline Added Acid & None & formic & formic & foriming & 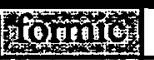 & formic & Mific & III] \\
\hline Added;acid, $\mathrm{M}$ & 0.000 & 0.094 & 0.188 & 10396 & (1376\% & 0.752 & 1966 & 0.36 \\
\hline Expected Acidity, M & -0.037 & 0.057 & 0.151 & 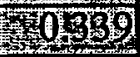 & 10:339 & 0.715 & 0339 & 聯01399 \\
\hline $\begin{array}{l}\text { Measured Total Acid } \\
\text { after acid addition, M }\end{array}$ & -0.037 & 0.042 & 0.071 & (1) & 6. & 0.436 & Whe & 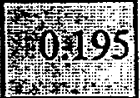 \\
\hline $\mathrm{H}_{2}$ Peak, volume $\%$ & 0.009 & 0.022 & 0.034 & 0.092 & 0.089 & 0.118 & 0.049 & 0.050 \\
\hline $\mathrm{H}_{2}$ Peak, lb/hrt & 0.002 & 0.005 & 0.008 & 0.023 & 0.022 & 0.029 & 0.012 & 0.012 \\
\hline
\end{tabular}

Hydrogen generation calculated based on a 6000 gallon DWPF Batch. 


\section{ACKNOWLEDGMENTS}

Thanks to Frances Williams, whose many hours of technical coverage (and working with our GCs) were invaluable to the success of these experiments. Frances Williams and Paul Monson completed the GC calibrations.

A special thanks to the ITS technicians, Sammie King, John Duvall, Mary Johnison, Vickie Williams, for their hard work in accomplishing these runs. In addition to working shifts to provide coverage throughout the runs, they set up equipmènt, calibrated analyzers, prepared chemicals, and performed analytical work to support this study.

Thanks also to Paul Monson, Russ Eibling and Jim Marek, who provided technical insight throughout the study. Alex Cozzi and Pat Toole completed the drying and vitrification of the melter feed. David Best and Eric Frickey completed the PCT, anion, elemental analysis, and redox measurements in the SRTC Mobile Lab.

Kim Willoughby, Andy Birk, Mary Johnson, and Chris Boley prepared the sludge simulant. 


\section{REFERENCES:}

1 D. M. Ferrara, B. C. Ha, D. P. Lambert, N. E. Bibler, Technical Assessment of a Sludge-Only Frit 200 Flowsheet with Copper (U), WSRC-RP-96-142, June 7, 1996

2 D.P. TR

$$
\text { TR O } 0 \text {, June 7, } 1996
$$

D. P. Lambert C. S. Boley, Alternative Tank 51 Sludge-Only Process Development for the Defense Waste Processing Facility (DWPF) (U), WSRC-RP-97-40, Rev. 0, February 12, 1997 $\therefore$

D. P. Lambert, C. S. Boley, Alternative Tank 51 Sludge-Only Process Development for the Defense Waste Processing Facility (DWPF) (U), WSRC-RP-97-40, Rev. 1, March 13, 1997

1 DWPF FSAR, WSRC-SA-6, Rev. 17.

3 D. P. Lambert, C. S. Boley, Altemative Tank 51 Sludge-Only Process Development for the Defense Waste Processing Facility (DWPF) (U), WSRC-RP-97-40, Rev. 1, March 13, 1997

$6 \quad$ K. G. Brown, C. M. Jantzen, and J. B. Pickett, The Effects of Formate and Nitrate on Reduction/Oxidation (Redox) Process Control for the Defense Waste Processing Facility (DWPF) (U), WSRC-RP-97-34, February 5, 1997

7 D. P. Lambert, C. S. Boley, Alternative Tank 51 Sludge-Only Process Development for the Defense Waste Processing Facility (DWPF) (U), WSRC-RP-97-40, Rev. 1, March 13, 1997

8 C.M. Jantzen, N.E. Bibler, D.C. Beam, C.L. Crawford, and M.A. Pickett, Characterization of the Defense Waste Processing Facility (DWPF) Environmental Assessment (EA) Glass Standard Reference Materiàl (U), WSRC-TR-92-346, Rev. 1, June 1, 1993. 


\section{Appendix A \\ Experimental Setup and Laboratory Procedure}

The six variability study experiments were conducted in the 772-T Laboratory. The experimental setup is summarized in Figure A1. The equipment and instruments used are described below:

Figure A1

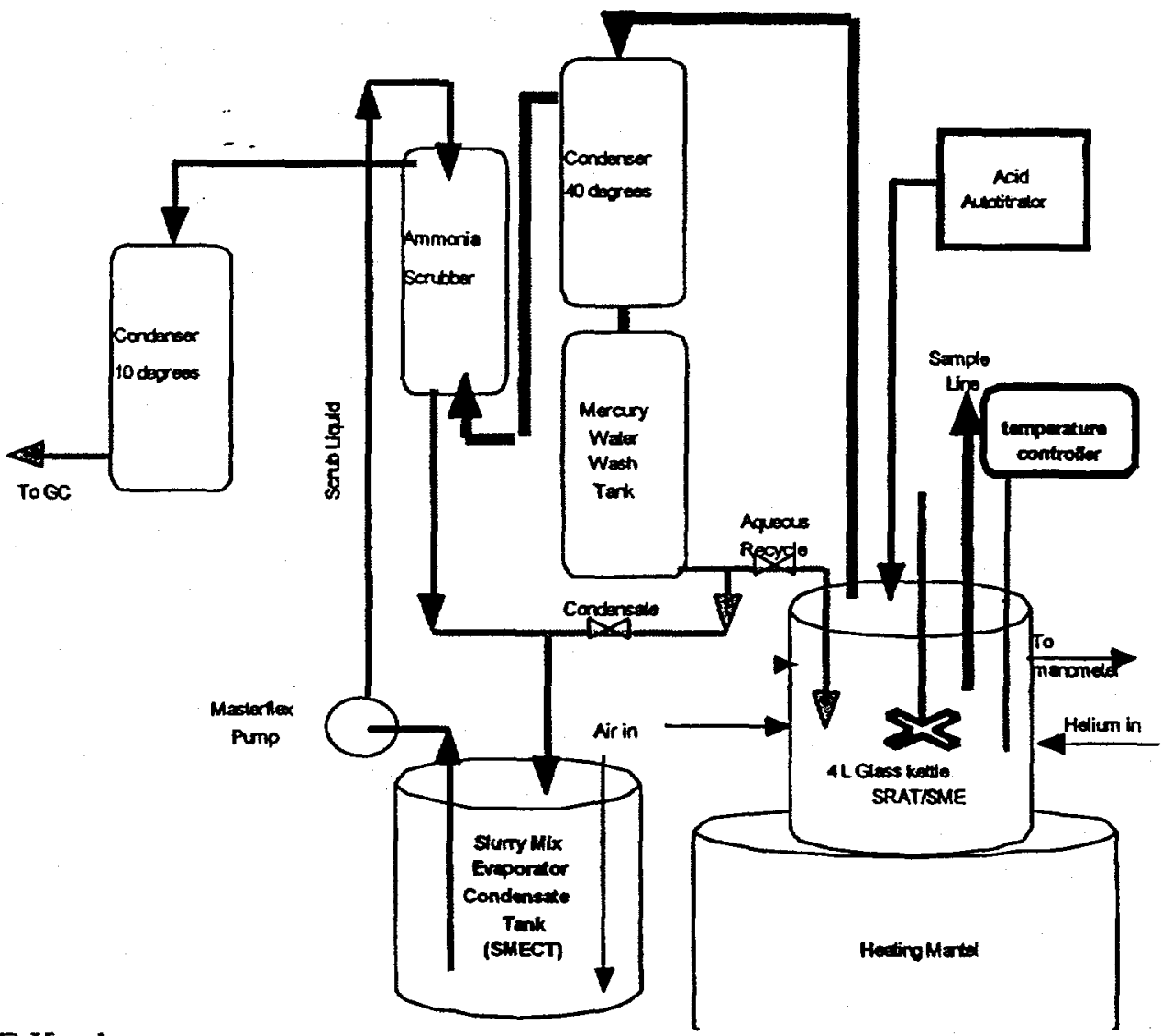

SRAT/SME Kettle

A four-liter Pyrex kettle with a glass lid was used for the variability study. The kettle lid contained the following seven openings or ports (Figure A2). The instrument that uses each of the ports is described below: 


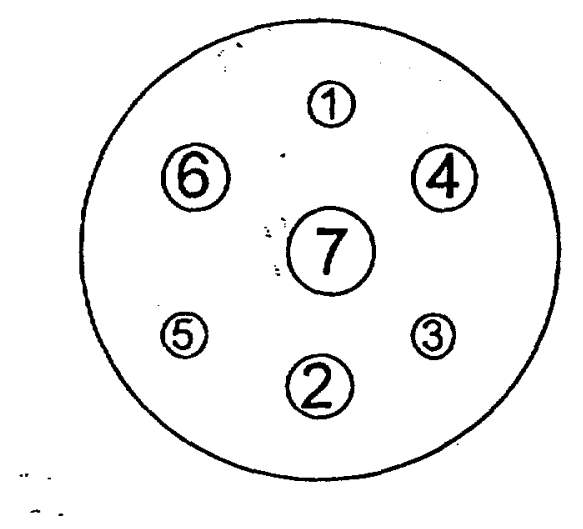

\section{Port 7 - Agitator}

The contents of the SRAT/SME kettle was mixed using an agitator. The agitator had two impellers, a bottom flat blade impeller and the upper marine impeller. A Variable Speed Mixer powered the agitator. A variac speed controller controlled the agitation speed.

Port 4 - $\mathrm{pH}$ Probe

A calibrated $\mathrm{pH}$ electrode was installed through the kettle top into the slurry. The electrode was connected to an Omega $\mathrm{pH}$ meter.

Port 6 - Slurry Sampler

A sampler was installed to allow the sampling of the SRAT/SME kettle contents as needed.

Port 3 - Antifoam addition Port

An antifoam addition port was designed to allow the addition of antifoam as needed.

Port 2 - Acid Addition

Nitric and formic acid were accurately metered into the kettle use a Mettler Toledo Autotitrator.

- Only one acid was present in the hood at a time to prevent the inadvertent addition of concentrated nitric acid to concentrated formic acid.

Port 5 - Air and Hetium purge

The inlet gas flows to the kettle were controlled by individual MKS Flow Meter connected to a MKS four-channel set-point controller. A separate air and helium purge was added to the kettle 
to produce a 0.5 volume \% helium flow entering the kettle. This was used as an internal standard to calculate the outlet offgas flow since it is difficult to measure reliably during SRAT and SME operations.

\section{Port 2 - Thermocouple}

RTD probes measured the Kettle slurry and SMECT liquid temperatures. The temperature signal was an input to the Dyna-sense ${ }^{\otimes}$ Benchtop Temperature Controller that controlled the slurry temperature as needed.

\section{Port 5 - Pressure Surge U-tube manometer}

The kettle pressure was limited to approximately 20 inwc by water filled U-tube manometer. Approximately 10 inches of water were in each leg of the manometer. The manometer would relieve if the pressure in the kettle exceeded approximately 20 inwc. It was also used to measure the pressure in the kettle vapor space during processing.

\section{SRAT/SME Kettle Mantle}

The four-liter Pyrex kettle rested in an $800 \mathrm{~W}$ mantle to allow temperature control of the kettle slurry. A Dyna-sense ${ }^{\otimes}$ Benchtop Temperature Controller controlled the power to the mantle.

\section{SRAT/SME Condenser}

The SRAT/SME condenser is a counter current heat exchanger. The offgas from the kettle enters the top of the condenser, flows through the shell of the heat exchanger and the cooled offgas exits near the bottom of the condenser. The cooled offgas enters the ammonia scrubber after exiting the condenser. The condensate drains by gravity to the Mercury Water Wash Tank (MWWT). The cooling water enters the top of condenser, flows through the heat exchanger tubes and exits at the bottom of the condenser. The cooling water was controlled at $40^{\circ} \mathrm{C}$ by a Haake constant temperature water bath.

\section{Mercury Water Wash Tank (MWWT)}

The MWWT collects condensate and traps elemental mercury. The condensate drains by : gravity to the Mercury Water Wash Tank. An underflow/overflow weir prevents the transfer of the dense mercury or floating organic from exiting the MWWT. The condensate is transferred either back to the kettle through port 6 during the reflux phase or forward to the Slurry Mix Evaporator Condensate Tank (SMECT).

\section{Ammonia Scrubber}

A laboratory scrubber filled with glass Raschig rings removes ammonia from the offgas between the SRAT condenser and the FAVC. The gas enters at the bottom of the scrubber and flows up through scrubber packing and exits at the top of the scrubber. The offgas from the scrubber is fed to the FAVC. The SMECT was filled with $500 \mathrm{ml}$ of a $\mathrm{pH} 2$ condensate at the 
start of each experiment. This liquid, plus any condensate produced during the experiments is used as the scrubbing liquid for removing ammonia from the offgas. A Masterflex ${ }^{\otimes}$ Pump pumped the liquid from the SMECT to the top of the ammonia scrubber. The liquid flows down the column through the packing and exits at the bottom of the scrubber. This liquid drains by gravity to the SMECT.

\section{Formic Acid Vent Condenser (FAVC)}

The FAVC is a counter current heat exchanger. The offgas from the kettle enters the top of the condenser, flows through the shell of the heat exchanger and the cooled offgas exits near the bottom of the condenser. The condensate drains by gravity to the collection area at the bottom of the FAVC. The cooling water enters the top of condenser, flows through the heat exchanger tubes and exits at the bottom of the condenser. The cooling water was controlled at $5^{\circ} \mathrm{C}$ by a Haake constant temperature water bath.

\section{SMECT Kettle}

The SMECT is used to contain the condensate collected from the SRAT/SME kettle and serve as the liquid scrubbing solution source for the ammonia scrubber. The SMECT liquid was maintained at temperature of $50^{\circ} \mathrm{C}$. A four-liter Pyrex kettle with a glass lid was used for the variability study.

\section{SMECT Kettle Mantle}

The four-liter Pyrex kettle rested in an $800 \mathrm{~W}$ mantle to allow temperature control of the kettle slurry. A Dyna-sense ${ }^{\circledast}$ Benchtop Temperature Controller controlled the power to the mantle.

\section{SMECT Air Sparge}

An air purge was introduced into the SMECT liquid to promote mixing. The air flowrate was controlled by a MKS flow controller and fed to the liquid through a fritted glass disk. This was to simulate the air sparge ring in the DWPF SMECT.

\section{Offgas Gas Chromatograph}

The offgas was monitored by an MTI gas chromatograph. Column A was an MTI MS5A 4m column with an argon carrier gas calibrated for helium, hydrogen, oxygen and nitrogen. Column B was an MTI poraplot Q 8m column with an argon carrier calibrated for carbon dioxide and nitrous oxide. The chromatogram was recorded by the MTI EZChrom software version 4 on a $\mathrm{PC}$ in the lab. 


\section{Laboratory Run Plan}

The experiments were controlled using the SRAT/SME Laboratory Run Plan, SRT-PTD-970021. The blank procedure is included below:

Run \#

Date:

\section{PREREOUISITES}

1. $\square$ Add sludge to kettle and add specified noble metals. Paste a copy of the noble metal additions in the log book. Transfer the required quantity and wash water \#1 (from the run sheet) to the kettle. Mark the current level on the kettle with a marker.

2. $\square$ Add $500 \mathrm{ml}$ of $\mathrm{pH} 2$ Nitric acid solution to SMECT.

3. $\square$ Prepare sufficient $90 \%$ formic acid and $50 \%$ nitric acid.

4. $\square$ Prepare $100 \mathrm{ml} \mathrm{lM} \mathrm{NaOH}$ solution or make sure sufficient solution is available.

5. Turn on cooling water to offgas condenser. Setpoint $=5^{\circ} \mathrm{C}$.

6. Make sure the GC computer has enough memory space for the run (at least 40 Mbyte).

7. Set the GC computer time equal to the clock time. Record the time in the log book.

8. $\square$ Turn on the $G C$ and its computer and make sure that the computer and $G C$ are a matching set.

9. Install the calibration gas cylinder to the $G C$ and let the $G C$ run five times. If at the end of five runs the GC reading is within $10 \%$ of the gas composition in the cylinder, print the calibration check results and write down "pre-cal check and run number" on the printout. Otherwise, select "Calibration" "Level 1" "OK" to calibrate the GC five times. At the end of five runs the GC reading should be within $10 \%$ of the gas composition in the cylinder. If it is not, contact the engineer. Print the calibration check results and write down "pre-cal check and run number" on the printout.

10. $\square$ Turn on the purge gas to kettle with $468.8 \mathrm{sccm}$ of air and $2.86 \mathrm{sccm}$ of helium. Turn on the air to the SMECT at $100 \mathrm{sccm}$. Connect the outlet flowmeter to perform the leak check. The outlet flow should be $\approx 600 \mathrm{secm}$. If it is not, tighten all connections until the system is leak tight. Write down the leak check in the log book.

11. $\square$ Disconnect outlet flowmeter.

12. $\square$ Make sure the He pressure is at 18 psi (inside the lab).

13. $\square$ Calibrate the PHA pump to provide a flow of $4.33 \mathrm{~mL} / \mathrm{min}$, if that has not been done.

14. $\square$ Transfer required PHA and wash water \#1(from run sheet) to the feed tank. Turn on PHA feed agitator. Setpoint $=$ Pump the PHA in the line up to the kettle \& rezero the pump (press the up and down arrows and the Cum.Vol.Read buttons at the same time.

15. $\square$ Calibrate $\mathrm{pH}$ probe and set up the $\mathrm{pH}$ meter to provide continuous reading.

16. $\square$ Add the first antifoam addition and wash water \#2 (from the run sheet) to the kettle.

17. $\square$ Turn on kettle agitator. Setpoint $=$

18. $\square$ Pull a $10 \mathrm{ml}$ sample (SRAT-01) from the kettle, record the weight, add $1 \mathrm{ml} 1 \mathrm{M} \mathrm{NaOH}$ solution, record the weight again and other information required on the run sheet. Label and send to lab for formate, nitrate and nitrite analysis.

19. $\square$ Remove the sampling device and install the nitric acid titrator to the same port.

20. $\square$ Set up flow from the SMECT to the scrubber by turning on the SMECT pump. Flow $=6$ ml/min.

21. $\square$ Insulate vessel and offgas lines.

22. $\square$ Start the GC for this run beginning with baseline reading for a few minutes. The beginning GC reading should-be approx. $0.5 \%$ helium and $99.5 \%$ air. If it is not, contact the engineer. Write down the GC time, filename and etc. in the log book. Record the baseline data on the data sheet.

23. $\square$ Make sure the reflux line is set up so that the condensate is sent to the kettle.

24. $\square$ Make sure the MWWT is filled to the top line with water. 
Run \#

Date:

\section{SRAT CYCLE}

1. $\square$ Start heating the kettle (Turn on power, setpoint at $93^{\circ} \mathrm{C}$, voltage load setting at 10 ). Record the run data every 20 minutes on the data sheet.

2. $\square$ Turn on heat to SMECT (Temp setpoint $=50^{\circ} \mathrm{C}$ ).

3. When kettle temperature reaches $70^{\circ} \mathrm{C}$, turn the voltage load setting to 8 .

4. $\square$ When the kettle reaches $93^{\circ} \mathrm{C}$, add required quantity of $50 \%$ nitric acid (from the run sheet) to the kettle at a rate specified on the ruin sheet and adjust the load setting to maintain the kettle at $93^{\circ} \mathrm{C}$. Write down the start and stop time for the addition on the run sheet.

5. $\square$ When the addition of nitric acid is complete, remove nitric acid titrator and install formic acid titrator to the port and add required quantity of $90 \%$ formic acid (from the run sheet) to the kettle at a rate specified on the run sheet and adjust the voltage load setting to maintain the kettle at $93^{\circ} \mathrm{C}$. Write down the start and stop time for the addition on the run sheet.

6. When the formic acid addition is complete, remove the titrator and install the sampling device to the port.

7. Pull a $10 \mathrm{ml}$ sample (SRAT-02) from the kettle, record the weight, add $1 \mathrm{ml} 1 \mathrm{MNaOH}$ solution, record the weight again on the run sheet. Label and send to lab for formate, nitrate and nitrite analysis.

8. $\square$ Add antifoam and wash water. Add the subsequent antifoams and wash waters (from the run sheet) to the kettle every 12 hours through the antifoam feeding port. Record the additions on the run sheet in the appropriate chronological position.

9. $\square$ Change the reflux line so that the condensate is sent to the SMECT.

10. $\square$ Change temperature setpoint to $110^{\circ} \mathrm{C}$ to begin heating the kettle to boiling. Set the voltage load setting to 6 after boiling is reached.

11. When kettle temperature reaches boiling, concentrate until the level in the SRAT is equal with the line drawn after the initial sludge addition.

12. When the line in the kettle has been reached, change the reflux line so that the condensate is returned to the kettle. Hold the kettle at boiling in the reflux mode for 12 hours while taking samples every 4 hours. Measure boil-up rate once every two hours (desired $3.33 \mathrm{~g} / \mathrm{min}$ ). Record the data on the run sheet.

13. $\square$ At the end of 12 hours of reflux, cool the kettle to sub-boiling. Pull a $125 \mathrm{ml}$ sample (SRATfinal) from the kettle, record the weight, add $1 \mathrm{ml} 1 \mathrm{M} \mathrm{NaOH}$ solution, record the weight again on the run sheet. Label and send to lab for formate, nitrate and nitrite analysis.

14. $\square$ Pump 2500 grams of condensate from the SMECT into a carboy. Record the initial level and the total grams pumped out on the run sheet. 
Run \#

Date:

To obtain the SME Run Sheet, enter the data from the SRAT Run Sheet in to the excel spreadsheet in the lab. (Make sure the file name corresponds to the run name). Only enter numbers. Go to the Sheet "SME Run Sheet" and print.

\section{SME CYCLE}

1. $\square$ Reduce the purge rate to $164.6 \mathrm{scc} / \mathrm{min}$ of air and $1.33 \mathrm{scc} / \mathrm{min}$ of helium.

2. $\square$ Decrease the SMECT pump flow from $6 \mathrm{mV} / \mathrm{min}$ to $3 \mathrm{ml} / \mathrm{min}$.

3. $\square$ Add the SME antifoam addition and wash water (from the SME run sheet) to the kettle.

4. $\square$ Open the PHA port for first frit addition and add frit, $90 \%$ formic acid and water per run sheet. Record the addition time and the quantity of each chemical on the run sheet

5. Heat to boiling to collect condensate to level marked on SRAT kettle at the start of the SRAT cycle.

6. After the desired level of the second condensate received, shut off the heater to cool the kettle to sub-boiling.

7. $\square$ Open the PHA port for second frit addition and add frit, $90 \%$ formic acid and water per run sheet. Record the addition time and the quantity of each chemical on the run sheet.

8. $\square$ Heat to boiling and begin collecting condensate \#3.

9. $\square$ Continue boiling until the target condensate level is received in the SMECT. (The kettle should contain $45 \%$ solids). Record the condensate level on the run sheet.

10. $\square$ Remove the kettle insulation and shut off the heater to cool the kettle to sub-boiling.

11. $\square$ Pull a $125 \mathrm{ml}$ sample (SME-final) from the kettle, record the weight on the run sheet. Do not add any $\mathrm{NaOH}$ solution. Label and send to lab for formate, nitrate and nitrite analysis.

12. $\square$ Stop GC and record the GC time and clock time in the log book. Stop recording run data on the data sheet.

13. $\square$ Install the calibration gas cylinder to the GC and run the post-cal check. If the check indicates OK, print a copy and write "post-cal check and run number" on the printout, then place the GC in standby. If the check is not within $10 \%$ of the cal gas composition, notify the engineer.

14. $\square$ Pump melter feed into a tared bottle. Record the weight on the run sheet.

15. $\square$ Pump out the SMECT. Record total amount collected throughout the run on the Run sheet.

16. $\square$ Complete pH meter post calibration check.

17. Install the outlet flow meter to the purge gas.

18. $\square$ Wen the kettle is $\operatorname{cool}\left(<50^{\circ} \mathrm{C}\right.$ ), record the outlet purge flow in the log book. (All 4 four channels).

19. $\square$ Turn off all instruments.

20. $\square$ Perform a wt\% solids analysis on the SME product. Verify with the engineer that the target has been met. 


\section{Appendix B \\ Scaling and Batching Calculations}

The variability study consisted of scaled DWPF SRAT and SME processing cycles. Each run was based on a 2000-gram addition of Tank 42 sludge simulant to the kettle. PCCS was used to determine the quantity of frit 200 required to make quality melter feed. Kevin Brown completed the PCCS calculations based on the sludge composition summarized in Tables B1 and B2. The PCCS calculated batching is summarized in Table B3.

\section{Table B-1 Tank 42 Simulant Sludge Composition}

\begin{tabular}{|l|r|rrrr|}
\hline Elementals, wt\% & \multicolumn{5}{c|}{ Best Estimate } \\
ADS Sample $\#$ & \multicolumn{1}{c}{ Average } & $94958 \mathrm{~A}$ & $94958 \mathrm{~B}$ & $94959 \mathrm{~A}$ & $94959 \mathrm{~B}$ \\
\hline $\mathrm{Al}$ & 7.43 & 7.7121 & 7.4313 & 7.3321 & 7.2285 \\
$\mathrm{~B}$ & & 0.0201 & 0.0203 & 0.0204 & 0.0199 \\
$\mathrm{Ca}$ & 2.74 & 2.718 & 2.67055 & 2.8267 & 2.7313 \\
$\mathrm{Cr}$ & 0.19 & 0.07685 & 0.07425 & 0.07965 & 0.08725 \\
$\mathrm{Cu}$ & 0.01 & 0.01295 & 0.0099 & 0.01615 & 0.01835 \\
$\mathrm{Fe}$ & 23.74 & 23.9423 & 23.6995 & 23.88335 & 23.4263 \\
$\mathrm{~K}$ & 0.24 & 0.245 & 0.2434 & 0.2324 & 0.2341 \\
$\mathrm{Li}$ & 0.00 & $<0.0082$ & $<0.0082$ & $<0.0083$ & $<0.0081$ \\
$\mathrm{Mg}$ & 1.09 & 1.1056 & 1.08815 & 1.0978 & 1.05535 \\
$\mathrm{Mn}$ & 3.09 & 3.12035 & 3.0741 & 3.11425 & 3.04895 \\
$\mathrm{Na}$ & 7.57 & 7.8758 & 7.7344 & 7.4382 & 7.2404 \\
$\mathrm{Ni}$ & 0.33 & 0.3316 & 0.3207 & 0.3608 & 0.3293 \\
$\mathrm{P}$ & 0.26 & 0.255 & 0.2414 & 0.2704 & 0.2699 \\
$\mathrm{~Pb}$ & 0.08 & 0.07115 & 0.0677 & 0.08455 & 0.0983 \\
$\mathrm{Si}$ & 1.53 & 1.60565 & 1.52735 & 1.58395 & 1.41735 \\
$\mathrm{Ti}$ & 0.06 & 0.0736 & 0.03525 & 0.06125 & 0.05685 \\
$\mathrm{Zn}$ & 0.12 & 0.1201 & 0.11795 & 0.12055 & 0.1188 \\
$\mathrm{Zr}$ & 0.11 & 0.1588 & 0.0977 & 0.0759 & 0.1174 \\
\hline
\end{tabular}


Table B-2 - Tank 42 Simulant Sludge Composition

\begin{tabular}{|l|c|c|}
\hline & \multicolumn{1}{c}{$\begin{array}{c}\text { Runs } \\
1 \mathrm{~V}-4 \mathrm{~V}\end{array}$} & \multicolumn{1}{c|}{$\begin{array}{c}\text { Runs } \\
5 \mathrm{~V}, 6 \mathrm{~V}\end{array}$} \\
\hline Total Solids, wt \% & $16.98 \%$ & $16.05 \%$ \\
\hline Insoluble Solids, wt \% & $13.61 \%$ & $12.59 \%$ \\
\hline Soluble Solids, wt \% & $3.37 \%$ & $3.46 \%$ \\
\hline Density & 1.1112 & 1.0896 \\
\hline Total Base pH 7, M & 0.408 & 0.433 \\
\hline Total Base pH 5.5, M & 0.528 & 0.536 \\
\hline Total Base pH 4.5, M & 0.686 & 0.647 \\
\hline Nitrite, mg/L & 8299 & 8049 \\
\hline Nitrate, $\mathrm{mg} / \mathrm{L}$ & 2965 & 2996 \\
\hline
\end{tabular}

Table B-3 - PCCS Batching for all experiments (DWPF Basis)

\begin{tabular}{|cc|}
\hline \multicolumn{2}{|c|}{ Oxide Fraction } \\
\hline Sludge & 0.260 \\
Frit & 0.740 \\
\hline Volume. & gallons \\
\hline Sludge & 5000 \\
Frit & 2175.6 \\
\hline SME & 4400.9 \\
\hline Mass Total & Solids. lbs \\
\hline Total & 24,151 \\
Sludge & 7,873 \\
Frit & 16,340 \\
\hline Mass Vitrified & Solids. 1bs \\
\hline Total & 22,038 \\
Sludge & 5,730 \\
Frit & 16,308 \\
\hline Calcine Factor \\
\hline Total & $91.25 \%$ \\
Sludge & $72.78 \%$ \\
Frit & $99.80 \%$ \\
\hline \multicolumn{2}{|c}{}
\end{tabular}

The Plan for the experiments is summarized below, based on 6000 gallon DWPF batches (Table B4) 
Table B-4 - Calculated Batching for all Experiments (DWPF Scale)

\begin{tabular}{|l|c|c|c|c|c|c|}
\hline \multicolumn{2}{|c|}{ IV } \\
Acid & $125 \%$ & $125 \%$ & $125 \%$ & Max & $137.5 \%$ & $125 \%$ \\
\hline Redox Target & None & $0.2 \mathrm{M}$ & $0.2 \mathrm{M}$ & None & $0.2 \mathrm{M}$ & $0.2 \mathrm{M}$ \\
\hline Sludge Batch size, gallons & 6,000 & 6,000 & 6,000 & 6,000 & 6,000 & 6,000 \\
\hline 50 wt \% Nitric Acid, gal & 200.0 & 106.8 & 107.6 & 106.8 & 119.7 & 105.0 \\
\hline $90 \mathrm{wt} \%$ Formic Acid, gal & 171.2 & 212.6 & 219.1 & 400.0 & 229.6 & 210.4 \\
\hline
\end{tabular}

Batch Preparation

The experimental setup was put together as described in Appendix A. The procedure for controlling these experiments is summarized in Appendix C. The sludge preparation for each of the experiments is summarized in Table B5. The sludge was added to the kettle (no SRAT product heel was used), then the noble metals and mercury were added to the sludge. Finally rinse water was used to ensure all of the materials were added to the kettle, including the rinse water. Weekly the antifoam solution was mixed by combining a 1 gram Dow Corning 544 antifoam with 9 grams of water to make a 1:10 antifoam solution. At the beginning of the runs, a $0.01 \mathrm{M}$ nitric acid solution ( $\mathrm{pH}$ 2) was prepared to serve as the scrubbing liquid at the beginning of the experiments.

Table B-5 - Tank 42 Flowsheet Sludge Preparation

\begin{tabular}{|c|c|c|c|c|c|c|}
\hline & $1 \mathrm{~V}$ & $2 V$ & $3 V$ & dV & $5 V$ & $6 \mathrm{~V}$ \\
\hline udge, $g$ & 2000.1 & 2000.0 & 2000.2 & 2000.0 & 2000.2 & 2000.0 \\
\hline wt \% solids & 16.98 & 16.98 & 16.98 & 16.98 & 16.05 & 16.05 \\
\hline Total solids, $\mathrm{g}$ & 339.6 & 339.6 & 339.6 & 339.6 & 321.0 & 321.0 \\
\hline $\mathrm{RuCl}_{3, \mathrm{~g}}$ & 0.1614 & 0.1617 & 1.7658 & 0.1587 & 0.1522 & 0.1523 \\
\hline $\mathrm{Rh}\left(\mathrm{NO}_{3}\right) \cdot 2 \mathrm{H}_{2} \mathrm{O}, \mathrm{g}$ & 0.3304 & 0.3307 & 1.9276 & 0.3247 & 0.3124 & 0.3121 \\
\hline 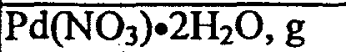 & 0.0312 & 0.0307 & 1.7568 & 0.0313 & 0.0294 & 0.0295 \\
\hline $\mathrm{AgNO}_{3}, \mathrm{~g}$ & 0.0827 & 0.0821 & 0.0075 & 0.0821 & 0.0778 & 0.0778 \\
\hline $\mathrm{HgO}, \mathrm{g}$ & 3.6301 & 3.6287 & 11.9649 & 3.6256 & 3.4313 & 3.4314 \\
\hline$\widehat{\mathrm{SeO}_{2}, \mathrm{~g}}$ & 0.0059 & 0.0059 & 0.0189 & 0.0061 & 0.0055 & 0.0054 \\
\hline $\mathrm{TeO}_{2}, \mathrm{~g}$ & 0.0467 & 0.0468 & 0.2038 & 0.0467 & 0.0442 & 0.044 \\
\hline Rinse I & 300.00 & 300.00 & 300.01 & 300.00 & 300.02 & 300.00 \\
\hline
\end{tabular}




\section{SRAT Cycle}

The SRAT cycle was designed to duplicate the processing in the DWPF SRAT cycle. The sludge was heated to $93^{\circ} \mathrm{C}$ then, the acids were added as summarized in Table B6. First nitric acid was added, then formic acid was added at a prototypic rate of $0.67 \mathrm{ml} / \mathrm{min}$. The acidified sludge was then heated to boiling, and the volume reduced back to $1800 \mathrm{ml}$. Then kettle was placed in reflux and boiling continue for a total of twelve hours. The kettle was sampled every four hours to track nitrite destruction. After the boiling was complete, the SRAT product was cooled and sampled."

Table B-6 - SRAT Cycle Additions

\begin{tabular}{|c|c|c|c|c|c|c|}
\hline & IV & $\mathrm{V}$ & $\boldsymbol{V}$ & & & \\
\hline Nitric Acid, ml & 66.34 & 35.45 & 35.71 & 35.45 & 39.70 & 34.8 \\
\hline Formic Acid, ml & 57.09 & 70.87 & 73.03 & 160.02 & 76.55 & 70. \\
\hline
\end{tabular}

SME Cycle

The SME cycle was designed to duplicate the processing in the DWPF SRAT cycle. Frit 200 , water, and $90 \mathrm{wt} \%$ formic acid were added to the SRAT product. The slurry was then heated to boiling, and the volume reduced back to $1800 \mathrm{ml}$. A second addition of frit 200 , water, and $90 \mathrm{wt} \%$ formic acid was added to the kettle. The total addition of frit 200 , water and formic acid is summarized in Table B7. The slurry was then heated to boiling, and the volume reduced until the product concentration was approximately $45 \mathrm{wt} \%$ solids. After the boiling was complete, the SME product was cooled and sampled.

Table B-7 - SME Cycle Additions

\begin{tabular}{|c|c|c|c|c|c|}
\hline & $1 \mathrm{~V}$ & $2 V$ & $4 V$ & $5 \mathrm{~V}$ & $6 V$ \\
\hline Frit $200, \mathrm{~g}$ & 603.89 & 592.56 & 637.4 & 608.52 & 601.82 \\
\hline Water, $\mathrm{g}$ & 1109.25 & 1088.45 & 1170.78 & 1117.73 & 1105.46 \\
\hline Formic Acid, $\mathrm{g}$ & 12.3 & 12.08 & 12.99 & 12.42 & 12.24 \\
\hline $\begin{array}{l}\text { SME Formic } \mathrm{Al} \\
\text { Addition for } \mathrm{Re}\end{array}$ & $\mathbf{1 7 . 9}$ & & & the ST & age \\
\hline Melter Feed, $\mathbf{g}$ & 1973.05 & 1879.47 & 1884.56 & 1992.59 & 1870.8 \\
\hline Condensate, $\mathrm{g}$ & & 2114.77 & 2522 & 2217.7 & 2228 \\
\hline
\end{tabular}


Table B-8 - Tank 42 Simulant Sludge Composition - Sodium Fusion and Microwave Preps

\begin{tabular}{|c|c|c|c|c|c|c|c|c|}
\hline Elementals, nt $\%$ & \multicolumn{3}{|c|}{ Sodium Fusion } & \multicolumn{5}{|c|}{ Microwave } \\
\hline ADS Sample \# & 94958A & 94958B & 94959A & 94959B & 94958A & 94958B & 94959A & $94959 \mathrm{~B}$ \\
\hline$\overline{\mathrm{Al}}$ & 7.7121 & 7.4313 & 7.3321 & 7.2285 & 6.7475 & 6.6694 & 6.3397 & 6.1324 \\
\hline $\mathrm{B}$ & 0.0201 & 0.0203 & 0.0204 & 0.0199 & & & & \\
\hline $\mathrm{Ca}$ & 2.4721 & 2.3792 & 2.5182 & 2.4225 & 2.9639 & 2.9619 & 3.1352 & 3.0401 \\
\hline $\mathrm{Cr}$ & 0.1389 & 0.1328 & 0.1453 & 0.1458 & 0.0148 & 0.0157 & 0.014 & 0.0287 \\
\hline$\overline{\mathrm{Cu}}$ & 0.0114 & 0.0086 & 0.0129 & 0.0187 & 0.0145 & 0.0112 & 0.0194 & 0.018 \\
\hline $\mathrm{Fe}$ & 22.9899 & 22.5339 & 22.8758 & 22.3531 & 24.8947 & 24.8651 & 24.8909 & 24.4995 \\
\hline $\mathrm{Li}$ & $-<00081$ & $<0,0082$ & $<0,0082$ & $<00080$ & $<0,0083$ & $<0.0081$ & $<0,0083$ & $<0,0082$ \\
\hline$\overline{\mathrm{Mg}}$ & 1.0108 & 0.9992 & 1.0147 & 0.9703 & 1.2004 & 1.1771 & 1.1809 & 1.1404 \\
\hline $\mathrm{Mn}$ & 2.8458 & 2.7835 & 2.8189 & 2.7637 & 3.3949 & 3.3647 & 3.4096 & 3.3342 \\
\hline $\mathrm{Ni}$ & 0.3187 & 0.3049 & 0.364 & 0.3159 & 0.3445 & 0.3365 & 0.3576 & 0.3427 \\
\hline $\mathrm{P}$ & 0.2342 & 0.2191 & 0.2498 & 0.2634 & 0.2758 & 0.2637 & 0.291 & 0.2764 \\
\hline $\mathrm{Pb}$ & 0.0511 & 0.0516 & 0.0593 & 0.0926 & 0.0912 & 0.0838 & 0.1098 & 0.104 \\
\hline $\mathrm{Si}$ & 1.3595 & 1.2715 & 1.4047 & 1.3193 & 1.8518 & 1.7832 & 1.7632 & 1.5154 \\
\hline $\mathrm{Ti}$ & 0.1048 & 0.0339 & 0.0838 & 0.0774 & 0.0424 & 0.0366 & 0.0387 & 0.0363 \\
\hline $\mathrm{Zn}$ & 0.1115 & 0.1084 & 0.1133 & 0.1108 & 0.1287 & 0.1275 & 0.1278 & 0.1268 \\
\hline $\mathrm{Zr}$ & & & & & 0.1588 & 0.0977 & 0.0759 & 0.1174 \\
\hline $\mathrm{K}-\mathrm{AA}$ & 0.245 & 0.2434 & 0.2324 & 0.2341 & & & & \\
\hline $\mathrm{Na}-\mathrm{AA}$ and $\mathrm{ICP}$ & 6.9269 & 6.8585 & 6.4413 & 6.8326 & 7.8758 & 7.7344 & 7.4382 & 7.2404 \\
\hline
\end{tabular}




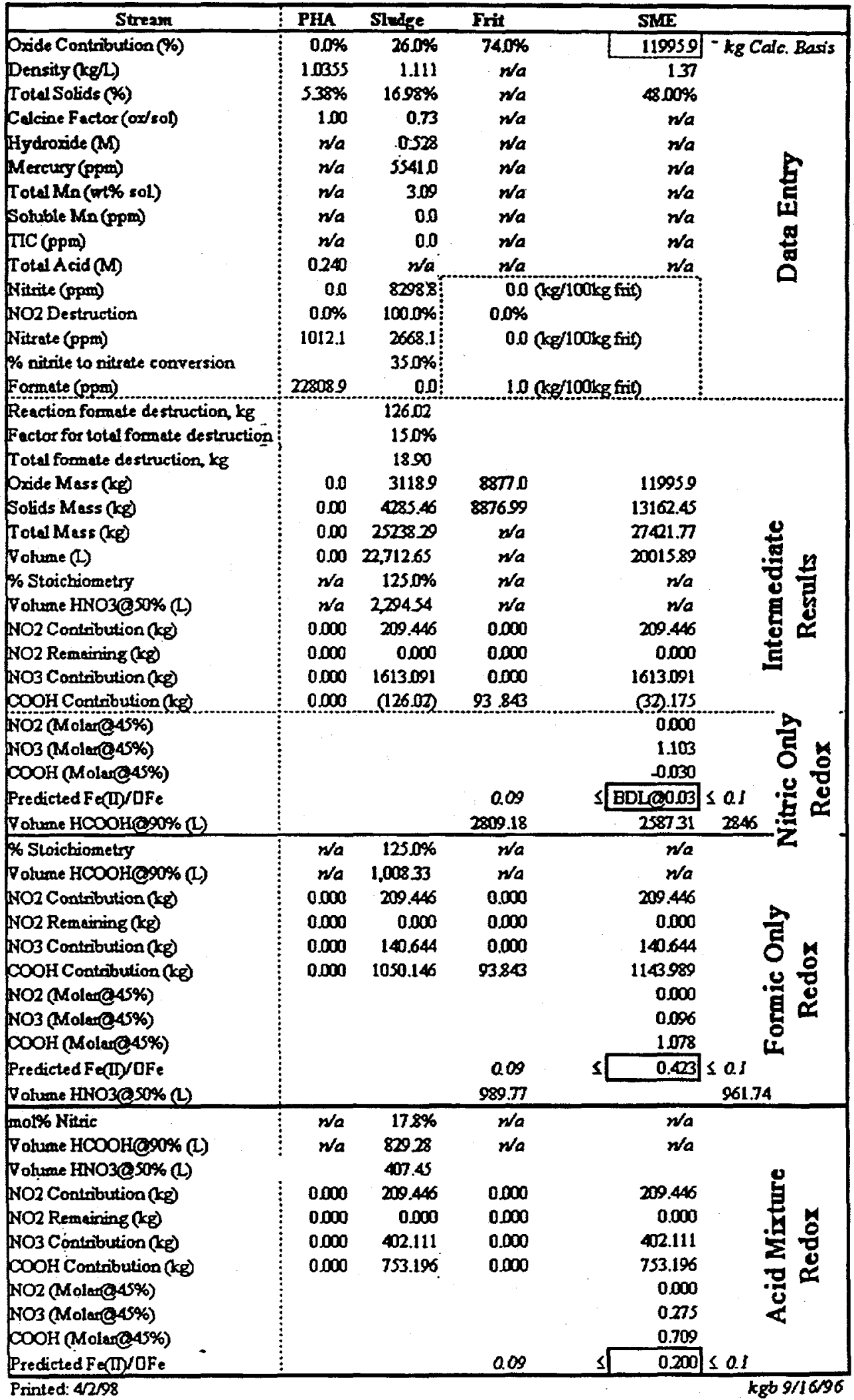

Table B-9- - Calculated Batching for all experiments (DWPF Scale) 


\section{Appendix C \\ Analytical Data}

The following is a summary of the Product Composition and Control System (PCCS) calculation of the sludge and frit batching required for the Tank 42 experiments based on the sludge (LPPPST-0) composition and the composition of frit 200 (PFSFT-0). The predicted composition of the SRAT product (SRAT Target) and SME product'(SME target) are summarized in the table below:

\section{Table C- 1}

Batohlng Information for Brar Batoh 0

Best Analyses of SRAT and FEED Vessels

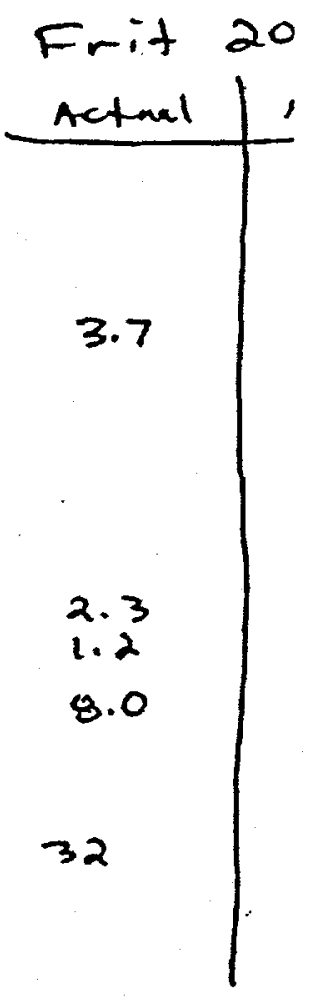

\begin{tabular}{|c|c|c|c|c|c|}
\hline Vessel & PRBT-0 & LPPPST-0 & PESFT - 0 & SRAT Target & SME Target \\
\hline Wt & 4.26 & 16.98 & 60.00 & 16.98 & 40.00 \\
\hline Cal'd NEt & 2.12 & 32.10 & 60.00 & 12.40 & 43.80 \\
\hline Het Ins & .00 & .00 & - & .00 & .00 \\
\hline Sp. Gr. & 1.03 & 1.21 & 1.50 & 1.11 & 1.37 \\
\hline Units & Ppm & Nt $\mid a\}$ & $k t(v)$ & $W t(a)$ & - $F t \geqslant(v)$ \\
\hline A1 & .00 & 7.43 & .00 & 7.43 & 2.65 \\
\hline $\mathbf{B}$ & 2169.14 & .02 & 3.73 & .02 & 2.77 \\
\hline Ba & .00 & .00 & .00 & .00 & .00 \\
\hline Co & .00 & 2.74 & .00 & 2.74 & .98 \\
\hline Cl & .00 & .00 & .00 & .00 & .00 \\
\hline Cr & .19 & .08 & .00 & .08 & .03 \\
\hline $\mathrm{Cs}$ & .00 & .00 & .00 & .00 & .00 \\
\hline cu & 209.37 & .01 & .00 & .01 & .01 \\
\hline $\boldsymbol{E}$ & .00 & .00 & .00 & .00 & .00 \\
\hline $\mathbf{F e}$ & 1104.97 & 23.74 & .00 & 23.74 & 8.46 \\
\hline $\boldsymbol{K}$ & 7952.30 & .24 & .00 & .24 & .09 \\
\hline L1 & .00 & .00 & 2.32 & .00 & 1.72 \\
\hline Mg & 12.14 & 1.09 & 1.21 & 1.09 & 2.28 \\
\hline Mn & 202.20 & 3.09 & .00 & 3.09 & 1.10 \\
\hline $\mathrm{Na}$ & 874.50 & 7.57 & 0.16 & 7.57 & 8.73 \\
\hline sd & .00 & .00 & - & .00 & .00 \\
\hline N1 & 120.75 & .33 & .00 & .33 & .12 \\
\hline P & .00 & .26 & .00 & .26 & .09 \\
\hline $\mathbf{P b}$ & .00 & .08 & - & .08 & .03 \\
\hline s1 & 80.87 & 1.53 & 32.72 & 1.53 & 24.75 \\
\hline Sol & .00 & .00 & - & .00 & .00 \\
\hline Th & .00 & .00 & .00 & .00 & .00 \\
\hline $\mathrm{T} 1$ & 649.86 & .06 & .00 & .06 & .02 \\
\hline $\mathbf{0}$ & .00 & .00 & .00 & .00 & .00 \\
\hline $2 n$ & .00 & .12 & - & .12 & .04 \\
\hline $2 x$ & 43.70 & .11 & .00 & .11 & .04 \\
\hline
\end{tabular}

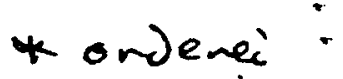

SRAT Target Information

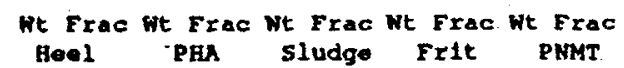


The following ternary diagram summarizes the acceptable Tank 42 sludge and frit 200 blend necessary to make acceptable glass. Since no PHA is used, the target is $19.3-26.0$ wt \% sludge oxides and 74.0 - $80.7 \mathrm{wt} \%$ frit oxides. Maximum sludge waste loading was used to maximize the waste loading in the glass.

Table C- 2

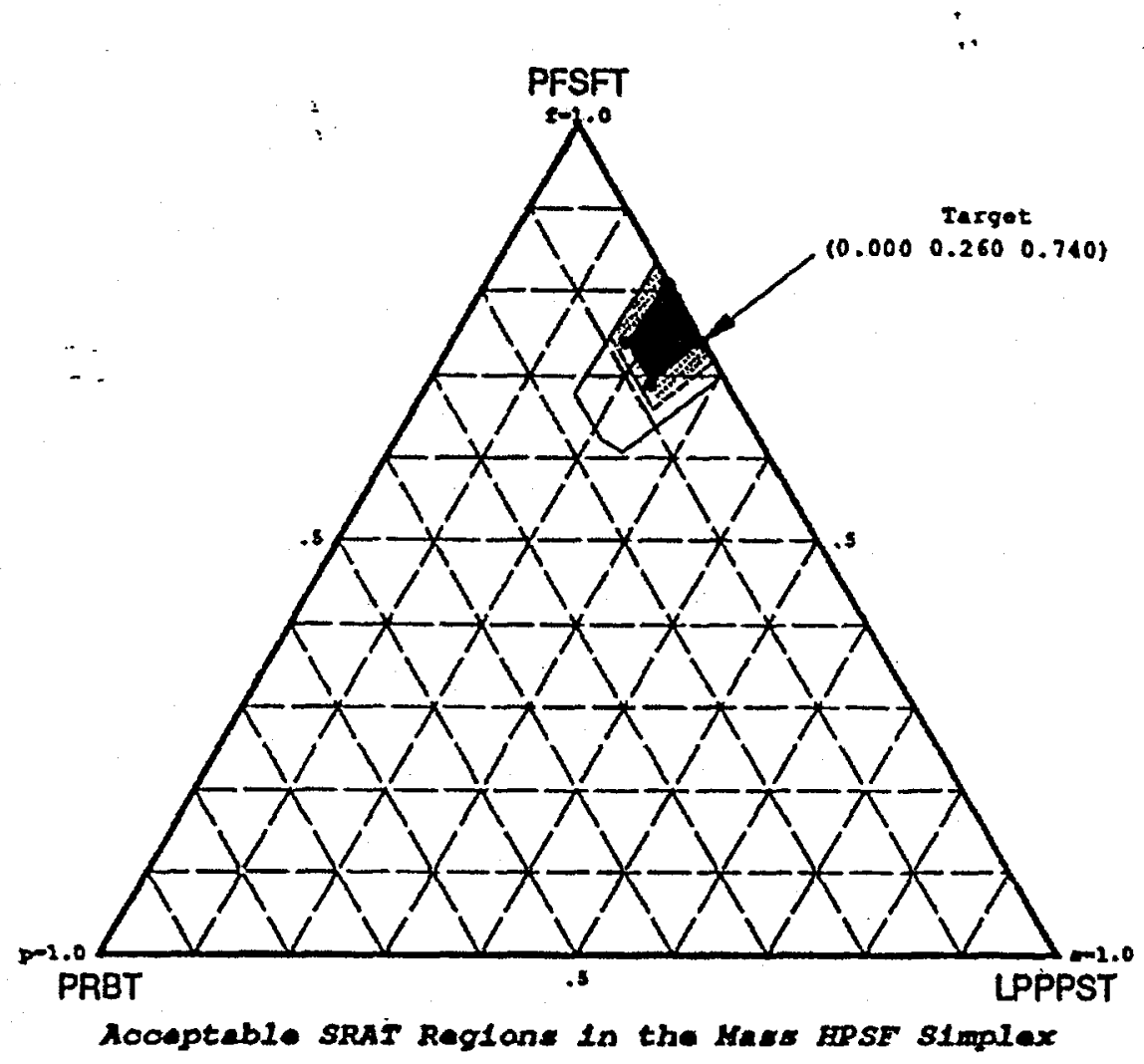

\begin{tabular}{|c|c|c|c|c|c|}
\hline SRAT $R$ & $\mathrm{R}$ (mass) & Coordi & $2<08$ & lght & n): \\
\hline $\begin{array}{l}\text { PRBT } \\
0.000\end{array}$ & $\begin{array}{r}\text { LPPPST } \\
0.260\end{array}$ & $\begin{array}{l}\text { PFSFT } \\
0.740\end{array}$ & $\begin{array}{l}\text { PRBT } \\
0.000\end{array}$ & $\begin{array}{r}\text { LPPPST } \\
0.193\end{array}$ & $\begin{array}{l}\text { PFSFT } \\
0.807\end{array}$ \\
\hline $\begin{array}{l}0.080 \\
0.080\end{array}$ & $\begin{array}{l}0.232 \\
0.182\end{array}$ & $\begin{array}{l}0.688 \\
0.738\end{array}$ & 0.003 & 0.185 & 0.812 \\
\hline
\end{tabular}

The Conetrainte Applieable to the Above rerget Blend are: Liquidus Temperature (C) < 1050 at a confidence of 95.0 High Viacoalty (polse) < 100 at a confidence of 95.0 Low V1scosity (polse) > 20 at a confldence of 95.0 ASTM C1285-94 B (NL(B) $g / L)<.7 .07$ at a confidence of 95.0 T102 (Wt $(v))<1.0$ at a confldence of 95.0 Cr203 (Wt (v)) $<0.3$ at a confldence of 95.0 P205 (Wt $(v)$ ( ) $<2.24$ at a confldence of 95.0 Cu (Wt $(v)) \leqslant 0.5$ at a confidence of 95.0 Predictability (Wt $(v))<-163.651$ at a confidence of 95.0 
The following data summarizes the results of the redox

Table C- 3 - SRTC Mobile Laboratory Analytical Results

Date: $10 / 16 / 97$

Customer: Dan Lambert

\begin{tabular}{|c|c|c|c|c|c|c|}
\hline Sample ID & Wejght(mg) & Dil.(uls) & $\mathrm{Fe} 2+\mathrm{abs}$ & FeTotal abs & $\mathrm{Fe} 2+/ \mathrm{Fe}^{3+}$ & $\mathrm{Fe} 2+/ \mathrm{Fe}$ total \\
\hline EASTD & 26.1 & 300 & 0.129 & 0.691 & 0.229 & 0.186 \\
\hline T2V1A & $\overline{35.4}$ & 500 & 0.021 & 1.666 & 0.013 & 0.012 \\
\hline T2V1B & 40.0 & 500 & 0.021 & 1.836 & 0.012 & 0.011 \\
\hline $\mathrm{T} 2 \mathrm{~V} 2 \mathrm{~A}$ & 37.0 & 500 & 0.028 & 1.669 & 0.017 & 0.016 \\
\hline T2V2B & 31.7 & 500 & 0.029 & 1.415 & 0.021 & 0.021 \\
\hline T2V3A & 30.5 & 500 & 0.021 & 1.201 & 0.018 & 0.018 \\
\hline T2V3B & 31.9 & 500 & 0.024 & 1.305 & 0.019 & 0.019 \\
\hline Average & & & & & & 0.016 \\
\hline T3V1.1A & 31.0 & 500 & 0.011 & 1.505 & 0.007 & 0.007 \\
\hline T3V1.1B & 45.1 & 500 & 0.013 & 2.042 & 0.006 & 0.006 \\
\hline T3V1.2A & $\overline{37.8}$ & 500 & 0.008 & 1.710 & 0.005 & 0.005 \\
\hline T3V1.2B & 37.3 & 500 & 0.008 & 1.651 & 0.005 & 0.005 \\
\hline T3V2.1A & 30.4 & 500 & 0.047 & 1.414 & 0.034 & 0.033 \\
\hline T3V2.1B & 34.6 & 500 & 0.054 & 1.662 & 0.033 & 0.032 \\
\hline T3V2.2A & 31.9 & 500 & 0.064 & 1.343 & 0.050 & 0.048 \\
\hline T3V2.2B & 42.5 & 500 & 0.086 & 2.021 & 0.045 & 0.043 \\
\hline T3V3.1A & 41.1 & 500 & 0.006 & 1.887 & 0.003 & 0.003 \\
\hline T3V3.1B & 33.5 & 500 & 0.006 & 1.722 & 0.004 & 0.004 \\
\hline T3V3.2A & 35.0 & 500 & 0.010 & 1.568 & 0.007 & 0.007 \\
\hline T3V3.2B & 42.2 & 500 & 0.010 & 1.983 & 0.005 & 0.005 \\
\hline Average & & & & & & 0.017 \\
\hline EASTD & 28.0 & 300 & 0.114 & 0.602 & 0.233 & 0.189 \\
\hline EAstd & 26.0 & 300 & 0.101 & 0.548 & 0.225 & 0.183 \\
\hline
\end{tabular}

* These were analyzed with a standard that had a higher than expected ratio. This was due to bad buffer $\mathrm{pH}$. You may want to bias correct to get the correct readings on the samples that follow. Fortunately

there was enough sample on one of the set to reanalyze with corrected buffer (noted with a " $x ")$.: 
Table C- $4-\mathrm{Fe}^{+2} / \mathrm{Fe}$ Total Redox Analysis

\section{12/16}

\begin{tabular}{|c|c|c|c|c|c|c|}
\hline & & & & & & \\
\hline 10 & Dilution & WEIGHT (mg) & $\mathrm{Fe} 2 t$ & FeTotal & $\mathrm{Fe} 2+/ \mathrm{Fe} 3+$ & Fe2+/Fe total \\
\hline & & & & & & \\
\hline Eastd & 300 & 27.9 & 0.110 & 0.601 & 0.224 & 0.183 \\
\hline TIV $1-1 \mathrm{~A}$ & 500 & 32.1 & 0.010 & 1.490 & 0.007 & 0.007 \\
\hline TIV1-1B & 500 & 32.1 & 0.004 & 1.468 & 0.003 & 0.003 \\
\hline TIV1-2A & 500 & 34.5 & 0.007 & 1.544 & 0.005 & 0.005 \\
\hline T1V1-2B & 500 & 32.8 & 0.006 & 1.556 & 0.004 & 0.004 \\
\hline TIV2-1A & 500 & 37.1 & 0.005 & 1.646 & 0.003 & 0.003 \\
\hline TIV 2-1B & 500 & 34.0 & 0.009 & 1.516 & 0.006 & 0.006 \\
\hline T1V2-2A & 500 & 31.6 & 0.008 & 1.410 & 0.006 & 0.006 \\
\hline TIV2-2B & 500 & 34.9 & 0.009 & 1.539 & 0.006 & 0.006 \\
\hline $\operatorname{TIV} 3-1 \mathrm{~A}$ & 500 & 36.9 & 0.008 & 1.722 & 0.005 & 0.005 \\
\hline$T 1 \vee 3-1 B$ & 500 & 34.7 & 0.009 & 2.900 & 0.003 & 0.003 \\
\hline$T I V 3-2 A$ & 500 & 34.8 & 0.016 & 1.623 & 0.010 & 0.010 \\
\hline$T 1 \vee 3-2 B$ & 500 & 38.0 & 0.017 & 1.680 & 0.010 & 0.010 \\
\hline T4V1-1A & 100 & 37.7 & 0.132 & 0.348 & 0.611 & 0.379 \\
\hline$T 4 V 1-1 B$ & 100 & 35.6 & 0.134 & 0.334 & 0.670 & 0.401 \\
\hline$T 4 V 1-2 A$ & 100 & 33.2 & 0.112 & 0.284 & 0.651 & 0.394 \\
\hline$T 4 \times 1-2 B$ & 100 & 34.6 & 0.127 & 0.335 & 0.611 & 0.379 \\
\hline T4V2-1A & 100 & 30.5 & 0.116 & 0.280 & 0.707 & 0.414 \\
\hline$T 4 V 2-1 B$ & 100 & 31.0 & 0.114 & 0.286 & 0.663 & 0.399 \\
\hline $\mathrm{T} 4 \mathrm{~V} 2-2 \mathrm{~A}$ & 100 & 31.7 & 0.106 & 0.288 & 0.582 & 0.368 \\
\hline$T 4 \vee 2-2 B$ & 100 & 33.2 & 0.107 & 0.307 & 0.535 & 0.349 \\
\hline$T 4 V 3-1 A$ & 100 & 35.6 & 0.099 & 0.339 & 0.413 & 0.292 \\
\hline$T 4 V 3-1 B$ & 100 & 34.0 & 0.095 & 0.319 & 0.424 & 0.298 \\
\hline$T 4 V 3-2 A$ & 100 & 38.1 & 0.112 & 0.337 & 0.498 & 0.332 \\
\hline
\end{tabular}


The following data supports the reported PCT results.

Table C- 5

Normalized Glass Compositions

$\begin{array}{ccccc}\text { Oxide } & \mathrm{T} 1 \mathrm{~V} & \mathrm{~T} 2 \mathrm{~V} & \mathrm{~T} 3 \mathrm{~V} & \mathrm{~T} 4 \mathrm{~V} \\ \mathrm{Al}_{2} \mathrm{O}_{3} & 6.13 \% & 5.90 \% & 6.11 \% & 5.65 \% \\ \mathrm{~B}_{2} \mathrm{O}_{3} & 8.03 \% & 8.40 \% & 8.19 \% & 8.26 \% \\ \mathrm{CaO} & 1.58 \% & 1.58 \% & 1.54 \% & 1.54 \% \\ \mathrm{CuO} & 0.01 \% & 0.01 \% & 0.01 \% & 0.01 \% \\ \mathrm{Fe}_{2} \mathrm{O}_{3} & 13.06 \% & 13.25 \% & 12.98 \% & 12.21 \% \\ \mathrm{~K}_{2} \mathrm{O} & 0.00 \% & 0.00 \% & 0.00 \% & 0.00 \% \\ \mathrm{Li}_{2} \mathrm{O} & 3.20 \% & 3.26 \% & 3.22 \% & 3.35 \% \\ \mathrm{MgO} & 2.09 \% & 2.03 \% & 2.09 \% & 2.08 \% \\ \mathrm{MnO} & 1.48 \% & 1.58 \% & 1.58 \% & 1.46 \% \\ \mathrm{Na} 2 & 11.24 \% & 10.71 \% & 11.30 \% & 11.44 \% \\ \mathrm{NiO}^{2} \mathrm{O} & 0.22 \% & 0.24 \% & 0.23 \% & 0.22 \% \\ \mathrm{P}_{2} \mathrm{O}_{5} & 0.28 \% & 0.29 \% & 0.33 \% & 0.26 \% \\ \mathrm{PbO}^{2} & 0.06 \% & 0.05 \% & 0.06 \% & 0.05 \% \\ \mathrm{SiO}_{2} & 52.48 \% & 52.55 \% & 52.23 \% & 53.32 \% \\ \mathrm{TiO}_{2} & 0.04 \% & 0.05 \% & 0.04 \% & 0.04 \% \\ \mathrm{ZnO} & 0.06 \% & 0.06 \% & 0.06 \% & 0.06 \% \\ \mathrm{ZrO}_{2} & 0.03 \% & 0.03 \% & 0.03 \% & 0.03 \% \\ & 100.00 \% & 100.00 \% & 100.00 \% & 100.00 \%\end{array}$


Table C- 6 Raw Analysis of PCT Leachates and Solution Standards

\begin{tabular}{cccccc}
\multicolumn{7}{c}{ Elemental Analysis $(\mu \mathrm{g} / \mathrm{ml})$} & & & \\
sample & $\mathrm{Na}$ & $\mathrm{Li}$ & $\mathrm{K}$ & $\mathrm{B}$ & $\mathrm{Si}$ \\
Blank-1 & $<0.530$ & $<0.020$ & $<0.600$ & $<0.180$ & $<0.180$ \\
Blank-2 & $<0.530$ & $<0.020$ & $<0.600$ & $<0.180$ & $<0.180$ \\
Arml & 10.2 & 9.81 & $<0.600$ & 13 & 43.1 \\
Arm2 & 9048 & 9.34 & $<0.600$ & 11.7 & 41.3 \\
Arm3 & 9071 & 9.75 & $<0.600$ & 12.8 & 43 \\
Std1 & & 9.41 & 9.82 & 19.7 & 50.2 \\
chkstd & 4.92 & 4.92 & 5.04 & 5.28 & 5.13 \\
ea1 & 382 & 98.8 & 1.23 & 360 & 560 \\
ea2 & 334 & 93.2 & 0.992 & 305 & 538 \\
ea3 & 320 & 89.9 & 0.975 & 285 & 524 \\
t1v-1 & 10.4 & 5.82 & $<0.600$ & 8.69 & 50.2 \\
t1v-2 & 10.1 & 5.57 & $<0.600$ & 8.41 & 47.2 \\
Std2 & & 9.74 & 9.72 & 19.6 & 51.2 \\
chkstd & 3.17 & 4.92 & 5.06 & 5.29 & 4.92 \\
t1 $\mathrm{v}-3$ & 10.4 & 5.59 & $<0.600$ & 8.46 & 48.9 \\
t2v-1 & 11.5 & 5.95 & $<0.600$ & 10 & 55.6 \\
t2v-2 & 11.9 & 6.07 & $<0.600$ & 9.77 & 57 \\
t2v-3 & 11.7 & 6.11 & $<0.600$ & 9.8 & 56.2 \\
t3v-1 & 11 & 5.68 & $<0.600$ & 9.12 & 50.8 \\
Std3 & & 9.64 & 9.88 & 20.5 & 50.7 \\
chkstd & 5 & 5 & 5.1 & 5.39 & 5.07 \\
t3v-2 & 11.2 & 5.9 & $<0.600$ & 9.27 & 50.5 \\
t3v-3 & 11.3 & 6.05 & $<0.600$ & 9.91 & 51.2 \\
t4v-1 & 12.9 & 6.48 & $<0.600$ & 10.5 & 56.6 \\
t4v-2 & 13.2 & 6.47 & $<0.600$ & 10.3 & 56.5 \\
t4v-3 & 13.4 & 6.48 & $<0.600$ & 10.9 & 60.4 \\
Std4 & & 9.38 & 9.87 & 20.1 & 49.2 \\
chkstd & 4.93 & 4.77 & 5.07 & 5.23 & 5.06
\end{tabular}

Where:

chkstd is the Mobile Lab standard to check instrument

Std1, Std2, Std3, and Std4 are multi-element solution standards submitted to verify analysis

Multi-Element ICP Standard Lot \# $691120 \pm 0.5 \%$

$\therefore \quad$ Al $4 \mu \mathrm{g} / \mathrm{ml} \quad \mathrm{K} 10 \mu \mathrm{g} / \mathrm{ml}$

B $20 \mu \mathrm{g} / \mathrm{ml} \quad$ Si $50 \mu \mathrm{g} / \mathrm{ml}$

$\mathrm{Fe} 4 \mu \mathrm{g} / \mathrm{ml} \quad \mathrm{Na} 81 \mu \mathrm{g} / \mathrm{ml}$

$\mathrm{Li} 10 \mu \mathrm{g} / \mathrm{ml}$ 


\section{DISTRIBUTION:}

L. M. Papouchado, 773-A

E. W. Holtzscheiter, 773-A

C.R. Goetzman, 773-A

C. T. Randall, 704-T

L.F. Landon, 704-1T

D. A. Crowley, 773-43A

J. R. Harbour, 773-43A

T. B. Edwards, 773-42A

R. A. Jacobs, 704-T

R. E. Eibling, 704-T

P. R. Monson, 704-1T

K. G. Brown, 704-1T

A. S. Choi, 704-1T

D. P. Lambert, 704-1 T

W. E. Daniel, 704-1T

M. F. Williams, 704-1T

T. L. Fellinger, 773-A

N. E. Bibler, 773-A

C. S. Boley, 703-H

M. N. Brosee, 704-S

J. F. Ortaldo, 704-S

W. D. Kerley, 704-S

S. L. Marra, 704-25S

R. E. Edwards, Jr. 704-25S

H. H. Elder, 704-S

M. R. Norton, 704-27S

J. E. Occhipinti, 704-27S

P. M. Patel, 704-27S

D. F. Gehr, 704-35S

J. P. Schwenker, 704-35S

S. G. Phillips, 704-27S

P. H. Werling, 704-27S

STI, 703-43A (4) 
Westinghouse

Savannah River Company

Alken. SC 29808
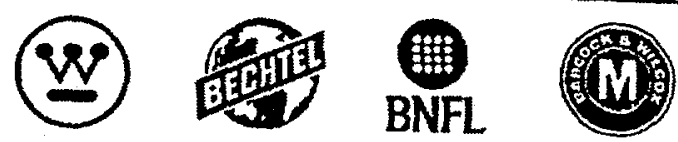

WSRC-RP-98-00149-TL, Revision 1

Keywords: DWPF, CPC, Tank 42

Sludge

Retention: Permanent

September 2, 1998

M. N. BROSEE, MANAGER

DEFENSE WASTE PROCESSING FACILITY

\section{TANK 42 SLUDGE-ONLY PROCESS DEVELOPMENT FOR THE DEFENSE WASTE PROCESSING FACILITY (DWPF) (U)}

In response to the Technical Task Request \#HLW/DWPF/TTR-970134, a series of laboratory scale process simulations were performed to ensure the current sludge-only flowsheet is acceptable for processing sludge batch IB in the DWPF Chemical Processing Cell (CPC). Sludge batch IB is the next sludge macrobatch that will be processed in DWPF, once the current Tank 51 sludge is exhausted (expected August 1998).

One processing change is that $10 \%$ more acid is required than is currently used to ensure the destruction of nitrite in a twelve-hour aqueous boil time in the SRAT cycle. The generation of hydrogen and nitrous oxide is well within the current DWPF safety envelop.

The report is being reissued to clarify the Product Consistency Test (PCT) results.

If you have additional questions regarding the attached report, please contact D. P. Lambert, 7-7680.

Ecubletracherter

E. W. Holtzscheiter, Manager

SRTC - Immobilization Technology Section 